\title{
Stone Artifacts From Agathonisi, Dodecanese, Greece: EVIDENCE OF INSULARITY
}

Eirene Poupaki ${ }^{1}$

\section{ABSTRACT}

The systematic excavation at Kastraki of Agathonisi island revealed the remnants of a fortified harbor, which developed commercial and political contacts with Miletos, the Ionic metropolis, and other cities of Asia Minor, as well as its neighboring or remote islands. These conclusions were provided by the well-studied findings of the excavation and can be also confirmed by the unpublished stone artifacts, such as vases, querns, and tools, which will be presented here. They were carved in local or imported rocks. The investigation of their origin elucidates the question of insularity, that is isolation and connectivity.

\section{KEYWORDS}

Agathonisi, Dodecanese, Stone, Vases, Querns.

\footnotetext{
${ }^{1}$ Dr. in Classical Archaeology. Hellenic Ministry of Culture and Sports, Directorate of Prehistoric and Classical Antiquities, Bouboulinas 20, 10672 Athens, Greece. Email: ipoupaki@culture.gr.
} 
Mare Nostrum, ano 2021, v. 12, n. 2

\section{Introduction}

Agathonisi, the northernmost island of the dodecanesian complex (fig. 1), is situated to the south of Samos and close to the Asia Minor coast. It is located at the southwestern end of the Menderes complex, so its geology is featured by the characteristic geomorphology of Menderes Massif, which is consisted of crystalline, semi-crystalline and schist limestones and limestone-schists (Panitsa \& Tzanoudakis, 1998, p. 96).

The island had been inhabited since the late $\mathrm{IV}^{\text {th }}$ millennium $\mathrm{BC}$, according to the findings from Kastraki, a rocky hill at the northern cost between Maistros and Anginaria Bay (Triantafyllidis 2015,96), whereas further traces of habitation of the III $^{\mathrm{rd}}$ millennium BC had been also recorded at Kephala and Kalyvia (Triantafyllidis 2015, 95, n. 3).

Agathonisi is known as Tragia or Tragaia by the ancient writers ${ }^{2}$ and it belonged to milesian territory with other neighboring islands, known as milesian (Patmos, Leros, Fournoi, Farmakonisi, Arkioi, Lipsi) (fig. 2). The key position of the island had been deployed by Milesians, who established garrisons during Classical and Hellenistic times, not only for mainland and maritime protection but also as an expression of their authority on the rural fortifications of these islands (Sarantidis, 2020). Important naval events took place nearby the island during the $5^{\text {th }}$ and $1^{\text {st }}$ cent. BC, like the battleship of Lade in 494 $\mathrm{BC}$; the tragic epilogue of the Ionian Revolution ended with the victory of the Persians shortly before the beginning of the Greco-Persian Wars (Triantafyllidis 2006, 2010, 2014 \& 2015; Triantafyllidis \& Karatasios 2015; Sarantidis 2015). Several other sites of Agathonisi (Kavi, Prezivolia, Alonia, Kleftos, et.c.) can be dated in the Hellenistic and Roman periods and a few sites (Tsagaris, Tholoi and Ag. Ioannis) in the Early-Christian and Early Byzantine periods (Triantafyllidis 2015, 95, n. 3).

\section{Excavation of Kastraki ${ }^{3}$}

The systematic excavation of Kastraki, inaugurated in 2006 by Pavlos Triantafyllidis, brought to light the archaeological remains of the fortified harbor and the naturally fortified citadel founded on the quarried rock of a hill (fig. 3). Important evidence from the site indicates the minoan presence on the island, whereas the archaic

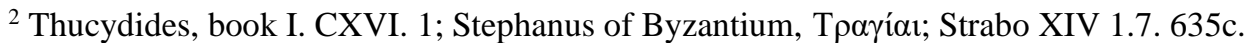

${ }^{3}$ A full publication of the material quoted in this paper in greek will appear in the two volumes of the excavation at Kastraki of Agathonisi, which is under preparation (Triantafyllidis, in press a and b). That is why further information about the size of the city, the population and relevant issues are not discussed here.
} 
pottery shows that the site continued to be inhabited during the $7^{\text {th }}$ and $6^{\text {th }}$ cent. (Triantafyllidis 2015,96 ). The fort is trapezoidal in plan and it is arranged in terraces formed by robust pseudo-isodomic walls of rectangular plan, which embrace the rock, following the natural slope of the rocky hill towards the sea (Triantafyllidis 2015, 97, fig. 4). The access was enabled through rock-cut staircases. The fortification walls are dated in the late $4^{\text {th }}$ and early $3^{\text {rd }}$ cent., but during the $2^{\text {nd }}$ and $1^{\text {st }}$ centuries some modifications of certain fortification walls had been realized, as part of a major military reinforcement of the fortification against piracy (Triantafyllidis 2015, 97-98, fig. 5). A quite interesting system of cisterns and wells, quarried in the rock, had been also excavated. The most impressive finding was a cistern hollowed in the rock and coated with hydraulic plaster at the top of the hill, which was located underneath a tower and remained in use from the late $2^{\text {nd }}$ cent. $\mathrm{BC}$ to the early $2^{\text {nd }}$ cent. AD (Triantafyllidis 2015, 98, fig. 6). The remnants of a workshop for murex processing to produce the dye of the tyrian purple, as well as pigments suitable for pottery coating and painting had been also investigated; they are dated from the $4^{\text {th }}$ cent. $\mathrm{BC}$ to $2^{\text {nd }}$ cent. AD (Triantafyllidis 2015, 98-100, fig. 7-9). Below a roman building of that workshop the remnants of a late-Hellenistic sanctuary, probably of the milesian city-deity, Apollo Didymeus, had been identified, too (Triantafyllidis 2015, 100-101, fig. 10). A built storage-room west of the southern fortification wall, had been excavated and from the clay findings was identified as a state apiary dated in the late $2^{\text {nd }}-1^{\text {st }}$ cent. BC (Triantafyllidis $2015,101-103$, fig. 12-13). The above-mentioned findings provide evidence about the significant economic activities which were taking place on the small island during Hellenistic and Roman period. Quite impressive are also the military installations for mooring warships located to the southeast side of the fort (Triantafyllidis 2015, 95).

The various mobile findings of that excavation provide clues about its commercial and political contacts during the Hellenistic period. Indeed, the discovered coins of the $4^{\text {th }}$ and $3^{\text {rd }}$ cent. $\mathrm{BC}$ belong to the milesian mint, whereas the pottery, the terracotta figurines, the textile weights, and the metallic artifacts (weapons, nails, etc.), which came to light insinuate that the small island of Agathonisi had established interrelations with other cities of Asia Minor, as well as with other islands, not only the closest ones but also certain further islands of the Dodecanese.

Several fragments of querns, vases, and tools had been investigated, which were carved in various rocks, local and imported. These stone artifacts enlighten the everyday life of the islanders. In that paper after a short presentation of the unpublished material 
(querns, vases, and tools ${ }^{4}$ ), there will be further discussion about the detected imports and the strong affiliations observed between the studied material and relevant findings from other sites (Asia Minor, Samos, Rhodes, Kos, and Nisyros).

\section{Vases}

The fragmented vases, which came to light during the excavation, belong to various types and were used mainly as household vessels. They are dated from the Classical to late Hellenistic period, besides a fragment of a prehistoric mortar $(\Lambda \Theta 229$-fig. 4). The vases discussed here can be divided into two parts: the local products and the imports. The local products are all unfinished and they are presented at the beginning.

\section{Local products (unfinished vases)}

It is worth noting that local and imported rocks were used for the carving of everyday implements. The semi-carved artifacts $(\Lambda \Theta$ 230-fig. 5, $\Lambda \Theta 42$-fig. 6, and $\Lambda \Theta$ 227-fig. 7) were carved in local limestone, however for the half-finished mortar $\Lambda \Theta 234$ a grey volcanic rock was used, which is identical to the grey koan rhyolite (Poupaki \& Chatziconstantinou 2001), a rock which was used for Hellenistic ő $\lambda \mu \mathrm{o}$ in Halasarna of Kos (Poupaki, 2017, no.10).

The unfinished vessels studied were mortars (ö $\lambda \mu o \mathrm{o}$ ) and they are all dated to Hellenistic period. Mortars, especially the biggest ones (ö $\lambda \mu \mathrm{ol}$ ), cannot be identified only as kitchen utensils, because they usually had industrial use, as they served to crush cereals before their grinding in the mills, to collect the liquid extract (oil mixed with water) from the oil presses, or even to mix building materials for the preparation of mortars (Poupaki, 2011 b, p. 61). These vases adopted features of the Hellenistic ö $\lambda \mu$ or discovered at various sites (Delos, Kos, Samos, Laconia, Corinth, and Asia Minor). Particularly, well-dated examples are the vases $\Lambda \Theta 230$ and $\Lambda \Theta 227$, which were found in a well's filling, dated in the early Hellenistic period, and associated to the clearing of the sanctuary at the second terrace of the site. Indeed, the unfinished mortar with spout $\Lambda \Theta 227$ is a quite common type during Hellenistic period, e.g., in Athens (Poupaki, 2000, no. 88), Corinth (Davidson, 1952, nos. 816-820, 827-829, fig. 19, pl. 61), Delos (Déonna, 1938, pp. 110114, pls. 319-326), Priene (Wiegand - Schrader, 1904, nos. 1541, 1559), Samos (Hiesel,

\footnotetext{
${ }^{4}$ The material presented here will appear with the registration number of the excavation. For the better view of the material see Table 1. For a full catalogue of the material, see Poupaki (in print a and b).
} 
1967, nos. 179-184, pl. 19), and Salamine of Cyprus (Chavane, 1975, nos. 4-8, pls. 1-2, 57). The vase $\Lambda \Theta 230$ resembles certain vessels carved in volcanic rocks or limestone from Kos, Allianoi, and Zeugma (Poupaki 2011a, vol. 2, no. A $\gamma 156$; Türkmen 2009, pp. 31-33, Parton 2013, p. 300, fig. 6ab, no. SM 7). The other two vases, $\Lambda \Theta 42$ and $\Lambda \Theta 234$, are surface finds, however their profile is reminiscent of Hellenistic vases: The vase $\Lambda \Theta$ 42 resembles to the delian ö $\lambda \mu$ o with slightly conical shape (Déonna 1938, figs. 294-296, 298), but also to laconian vases, which were mainly used as cinerary urns (Poupaki 2006, nos. 17 and 26; Poupaki 2019, no. 19). The vase $\Lambda \Theta 234$, even in an early processing stage reminds us of the Hellenistic mortars of Pompei (Poupaki 2011b, pl. 9b).

\section{Imported vessels}

The most elaborate vases found in the excavation were all imported. Two of them were carved in the same rock $(\Lambda \Theta 228$ and $\Lambda \Theta 60)$, which was probably quarried from a neighboring island (Samos), whereas the third $(\Lambda \Theta 44+62 \mathrm{AB})$ was probably imported from a remote one (Nisyros).

The shallow two-handled bowl $(\Lambda \Theta 228$-fig. 8), which was carved in soft yellowish limestone, is a remarkably interesting vessel because of its shape, its material, and its use. Its shape looks familiar, because it looks like the smallest mortars, which were household utensils useful for the pounding of pulses, the mixing of spices and seasonings or the squeezing of fruits for the extraction of juices with the aid of a spout. However, they were also laboratory instruments used for the pulverizing of chemical substances, drugs, and cosmetics. In certain areas of Asia Minor were discovered in graves, as grave goods ${ }^{5}$. Additionally, the characteristic lugs of the vase, which are reminiscent of the spoolshaped lugs of the early bronze age mortars (Mylonas 1959; Runnels 1988), are quite common on Archaic pottery ${ }^{6}$ and on Archaic, Classical and Hellenistic stone vases ${ }^{7}$.

A vase from Kition of Cyprus dated before the Hellenistic period (Salles-Chavane, 1993, p. 94) resembles the quoted vase, which is also alike a Hellenistic samian vase found in Aegina carved also in soft sandstone, which bears the same tool marks (point marks) on its inner surface (Hoffelner 1996, 45-46, no. S40). The Agathonisi vase $\Lambda \Theta$

\footnotetext{
${ }^{5}$ For relevant bibliography, see Poupaki (2011b, p. 55 and 2017, p. 75).

${ }^{6}$ E.g., an Archaic four-handled clay plate in British Mus., probably from Knidos (Datcha) Peninsula: Attula (2006, pp. 87, 90, cat. no. 3, figs. 8, 9).

${ }^{7}$ These lugs are attested on an Archaic three-handled bowl from the southern cemetery of Syracuse (Paolo Orsi Mus., no. 45), but also on Delian marble vases: Déonna (1938, fig. 137).
} 
228 is carved in soft brownish sandstone, which is not local and resembles the rock of the samian vase. As a matter of fact, marl limestone had been quarried in southern Samos and especially close to Pythagoreio since the Archaic period and is considered to have been exported $^{8}$. Similar porous limestone and sandstone were widely used in the Archaic period and they were extracted from Aegina, Corinth, and Rhodes, where major quarries were opened since the Archaic period (Kokkorou-Alevras et al., 2014, nos. 91-99, 105114, 619, 962-975). In Cyprus, the soft limestone was used for vases even in Roman times (Chavane, 1975, pp. 15-16, nos. 11-13; Salles \& Chavane, 1993, pp. 337-338, no. 803).

The vase $\Lambda \Theta 228$ was found in the filling of a well, in a context dated from the $4^{\text {th }}$ to $2^{\text {nd }}$ cent. BC. Its close resemblance to the Hellenistic samian vase and the preHellenistic vases from Kition of Cyprus lead us to consider it as late Archaic or Classical and to think that it was imported from Samos.

That vase is also interesting because of the absence of abraded internal surfaces, which may indicate that it was not used as a mortar. Its friable rock was unsuitable for a utilitarian article. That is why ritual use seems more probable. Indeed, similar vases are usually depicted on vase paintings on scenes relevant to sacrifices and they were the containers of the holy water for the sprinkling of the altar before the sacrifice, known as $\chi \varepsilon ́ \rho v i \beta \varepsilon \varsigma^{9}$.

Another vase, a bigger bowl with a rectangular handle with a curved profile and slightly elevated base ( $\Lambda \Theta 60$-fig. 9), is carved in similar limestone, probably of the same provenance as the previous vase. Its profile and the well-elaborated surfaces recall the Classical and Hellenistic vases carved in marble (mostly parian ${ }^{10}$, but also from elsewhere ${ }^{11}$ ) and in volcanic rocks (Vlachoyanni, 2012, pp. 41-42). It can be dated to the Hellenistic period, because of its features and of the context of the tank, where it was found (its context is dated from the $4^{\text {th }}$ cent. BC to $1^{\text {st }}$ cent. AD).

The most impressive vase studied is a ö $\lambda \mu \mathrm{S}$ on a high base, which had been restored from several pieces $(\Lambda \Theta 44+62 \mathrm{AB}-$ fig. 12). It was found in a layer dated in late Hellenistic-early Roman period and resembles to some Hellenistic parallels from Delos,

\footnotetext{
${ }^{8}$ Ancient quarries of soft limestone are located at Aspros Kavos in the surroundings of Pythagoreio and the underground quarries of Agiades and these on Katarouga or Koutsodonti hill between Pythagorio and Chora: Kokkorou-Alevras et al. (2014, pp. 24-25, nos. 45, 46 \& 50); Tsakos \& Viglaki-Sofianou (2012, p. $18)$.

${ }^{9}$ For the marble $\chi \dot{\varepsilon} \rho v i ß \varepsilon \xi$ : Poupaki (2011b, pp. 56-60).

${ }^{10}$ E.g. an unpublished vase from Kos in the deposit of the Castle of Nerantzia (fig. 10-22).

${ }^{11}$ E.g. a similar vase carved in koan marble: Poupaki (2011a, vol. 2, no. A $\gamma 185$ ) (fig. 11-23). 
Amorgos and in Marmaris museum, all unpublished. A similar vase on a high stand carved in koan marble can be dated in the same period (Poupaki 2011, vol. 2, no. A $\gamma$ 97). The vase is often depicted on black-figure vases ${ }^{12}$ and is also imitated in coroplastic syntheses ${ }^{13}$ of the Classical and Hellenistic period. It had been used for the preliminary crushing of the grains by means of a long and heavy pestle (ü $\pi \varepsilon \rho \circ v)^{14}$. Bigger vases of

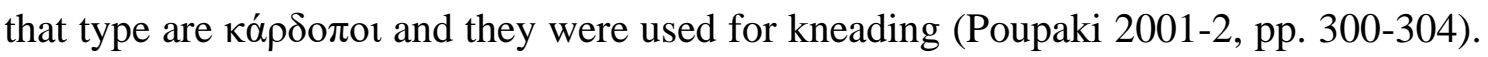
The vase preserves traces of repair, that is a square socket on the base. The sockets on the stone household vessels used for the insertion of metallic clamps prove that the repairs of these vases are quite common, probably because of their high cost ${ }^{15}$. It is carved in dark grey volcanic material which resembles strongly the nisyrian lava.

\section{Pestles}

Mortars were in use together with the pestles. In Agathonisi, simple elongated pebbles of local origin were used as pestles, for crushing or mixing various substances in stone or clay vases $(\Lambda \Theta 107, \Lambda \Theta 231 \text { - fig. } 13 \text { - and } \Lambda \Theta 237)^{16}$. Even though, a fragment of an $̋ \pi \varepsilon \rho o v$ was carved in purplish volcanic rock $(\Lambda \Theta 235$-fig. 14), non-local, which can be considered as an import. The most impressive pestles found are these in the form

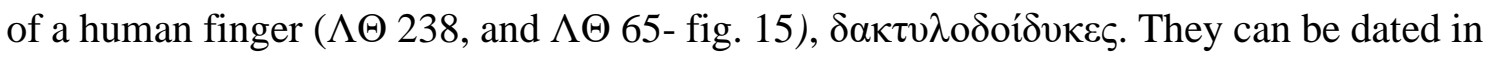
the Hellenistic age, basing on their context ${ }^{17}$ and their counterparts from the bibliography ${ }^{18}$. The best-preserved finger-pestle $(\Lambda \Theta 65)$ is carved in white fine-grained

\footnotetext{
${ }^{12}$ E.g. scyphus in Canellopoulos Mus. of Athens (no. 384), lekythos from Serpieri collection and kylix of New York Metropolitan Mus. (no. L.1982.110): Maffre (1975, fig. 2); Sparkes (1962, pl. VII.2); Neils (2004, fig. 4.4); Tsoukala (2009, figs. 9 - 10, 13).

${ }^{13}$ E.g. a coroplastic synthesis in Polygyros Mus. and another one from Tanagra cemetery in Louvre Mus. (CA 458): Kaltsas (2003, pl. 72); Tsoukala (2009, fig. 1); Pottier (1900, p. 512, pl. X.1).

${ }^{14}$ Déonna (1938, p. 106, figs. 133.2 and p. 50).

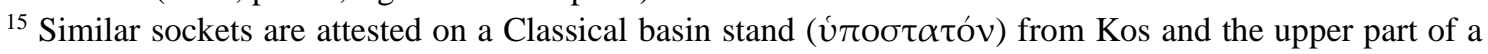
pompeian mill from Parion at the Marmara Sea: Poupaki (2012, vol. 2, no. Y4); Takaoğlu (2008, pp. 676677, nos. 6-7, fig. 7b).

16 They can be compared to implements from Delos, Knossos, and Tarsos: Déonna (1938, 116); Sackett \& Cocking (1992, pp. 393-394, nos. S3, S13a-b, S24 \& S55a, pls. 325-326); Goldman (1950, vol. 1, p. 387).

17 The pestle $\Lambda \Theta 231$ was found in a well, in a layer dated between $4^{\text {th }}$ and $2^{\text {nd }}$ cent. B.C.

18 The finger-pestles are quite usual in the Hellenistic period, but they can be dated since the Archaic period (basing on the inscribed counterparts from Athena Lindia Sanctuary in Rhodes). The findings from Agathonisi are reminiscent of the delian and corinthian finger-pestles: Déonna (1938, p. 118, fig. 353); Davidson (1952, p. 193, no.1434, pl. 86).
} 
marble, which could be Parian ${ }^{19}$ or Milesian ${ }^{20}$ or even from the neighboring island of Fourni $^{21}$.

\section{Querns}

\section{Saddle querns}

The earliest millstones from Agathonisi are saddle querns $(\Lambda \Theta 103, \Lambda \Theta 115, \Lambda \Theta$ 126, and $\Lambda \Theta 226$-fig.16). Saddle querns were the simplest devices for hulling grain; they were long oval slabs of stone, on which the grains broke open through the reversible movement of a grinder, usually a simple pebble, small enough to fit in one' $\mathrm{s}$ hand, or a similar slab with one flat side (Poupaki 2014-15, pp. 13-15; Poupaki 2017, pp. 79-80). Saddle querns from Agathonisi were carved in greyish volcanic material and they were probably imported $^{22}$, because of the lack of volcanic rocks on the island. Their origin does not help their dating. Typically, they can be judged as prehistoric; however, in certain areas saddle querns were used until the $5^{\text {th }}$ cent. $\mathrm{BC}^{23}$. A spherical grinder $(\Lambda \Theta 43$-fig. 17$)$, small enough to be held in a human hand, was probably in use with a saddle-quern.

\section{Olynthian mills or hopper-rubbers}

Most of the querns studied are olynthian mills $(\Lambda \Theta 46, \Lambda \Theta 109, \Lambda \Theta 111, \Lambda \Theta 112$, $\Lambda \Theta$ 113, $\Lambda \Theta$ 127, $\Lambda \Theta 217, \Lambda \Theta 218, \Lambda \Theta 219, \Lambda \Theta 220, \Lambda \Theta 223, \Lambda \Theta$ 225-fig.18). Olynthian mills, also known in the literature as hopper-rubbers, are rectangular-shaped friction grain mills the movable part of which was the upper millstone (ővos $\dot{\alpha} \lambda \varepsilon \tau \tilde{\omega} v$ ) while the lower ( $\mu$ v́$\lambda \eta)$ was fixed on a stable surface $(\tau \rho \alpha ́ \pi \varepsilon \zeta \alpha)$. The upper stone was hollowed out as a hopper to receive and funnel the cereals on the grinding surface of the lower mill through the slot which was carved on the bottom of the hopper. Grinding is

\footnotetext{
${ }^{19}$ A finger-pestle from similar marble was also found in Halasarna and the origin of the marble is thought to be parian: Poupaki (2011a, no. 82). Parian marble was ideal for vases since the late $6^{\text {th }}$ cent. BC: e.g., perirrhanteria of Athenian Acropolis: Wagner (1997, p. 132). The thin-walled luxurious pyxides, known as

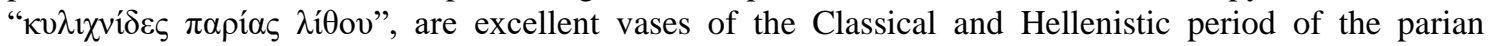
workshop: Robinson (1946, pp. 246-247, note 25); Jucker (1970, p. 182); Zaphiropoulou (1973); Colivicchi (1995); De Sienna, Lazzarini \& Cancelliere (2012); Gaunt (2013); Brecoulaki, Kavvadias \& Verri (2014); Brecoulaki \& Kavvadias (2019).

${ }^{20}$ Milesian marble is pure white and fine-grained, whereas the marble quarried at Herakleia on Latmos since the $6^{\text {th }}$ cent. BC was white and coarse-grained: Peshlow-Bindokat (1981 and 1994).

${ }^{21}$ Fourni marble, quarried at the western coast of the island at Petrokopio, was white, very fine-grained with rare grey spots or yellowish tinge: Lazzarini-Cancelliere (2000, p. 52).

22 The major provenance regions, where similar volcanic rocks were quarried, are Saronic Gulf (andesite) and Kos (rhyolite): Poupaki (2014-15, pp. 14-15, notes 24-27 \& 2016, p. 79, notes 138-142).

${ }^{23}$ E.g., in Troad: Takaoğlu (2008, p. 673).
} 
conducted by the to-and-fro movement of a rectangular shaped grinder on the rectangular quern, by means of a long lever ( $\kappa \dot{\pi} \pi \eta)$, which was fixed on special slots at each end of the upper millstone and held firmly in place by iron rods; finally, at one end of the upper millstone the lever was fitted over a pivot. The grinding surfaces may bear diagonal parallel striations, which could indicate a herringbone pattern, or alternated series of diagonal and horizontal striations. Chronologically, they may be placed approximately in the Classical to Hellenistic period, but in some cases their use may have arrived as late as in the Roman period (Poupaki 2014-15, pp. 17-19; Poupaki 2017, pp. 81-82). Agathonisi olynthian mills are carved in grey vesicular lava, which is reminiscent of the nisyrian volcanic tuff quarried in the open-air quarries and the subterranean galleries of Argos (Poupaki, in print c). Nisyros was famous for the manufacture of mills in antiquity, but until nowadays the nisyrian products had been detected securely only at the neighboring Halasarna of $\mathrm{Kos}^{24}$. There is, therefore, evidence for the high commercial value of these mills.

However, there are some sporadic findings carved in rocks like koan rhyolite $(\Lambda \Theta$ 221-fig.19), the andesite from Aegina or other sites of Saronic Gulf ( $\Lambda \Theta$ 45-fig.20), as well as some of unknown origin $(\Lambda \Theta 1, \Lambda \Theta 110, \Lambda \Theta 222, \Lambda \Theta 224$, fig.21). The last two hopper-rubbers had circular hopper, they are curved in grey non-porous volcanic rock and they must be derived from a single workshop, whose location is under research ${ }^{25}$. According to R. Frankel (Frankel, 2003, p. 9), they belong to the main greek type of olynthian mill. Some querns of that type were found in the vicinity of the athenian acropolis (Poupaki, 2014-15, nos. 64, 65, 66, 67, 68).

The hopper rubber $\Lambda \Theta 221$ (fig.19) is carved in a rock, which resembles to the koan olynthian mills carved in koan rhyolite, which are not quite common and follow the highquality nisyrian mills (Poupaki, 2011b, nos. 32-33). The use of koan rhyolite was systematized in Roman times for the carving of rotary querns ${ }^{26}$, which were dominant

\footnotetext{
${ }^{24}$ The applied archaeometric methods on the millstones from ancient Halasarna (Kardamaina, Kos) showed that the olynthian mills from the excavation were of Nisyrian origin and that they were either from the open-air quarry, either from the underground quarry of Argos: Katerinopoulos et al. (2016); Katerinopoulos, Mavrogonatos \& Poupaki (2017).

25 There is a current research about the origin of the hopper-rubbers of that type, which were discovered in Athens, during the excavation for the construction of METRO Railway Station "Acropolis" in Makrygiannis plot: Poupaki (2014-15, nos. 64-68).

${ }^{26}$ Rotary querns superseded the other types of querns and have remained in use ever since. They are roundshaped querns used for the grinding of cereals through the circular movement of a round-shaped grinder above a similar quern. The grinder is pierced in the middle to enable the spindle to pass through the stone and allow the upper stone to move smoothly. The hopper is curved around the hole of the upper stone.
} 
until the byzantine era, and despite the lack of archaeometric origin studies, there is strong evidence that the koan products were exported (Poupaki, 2011a, vol. 1, pp. 103-104). The lack of archaeometric methods applied on samples of these findings leaves some doubt about the exact origin of that quern, as well as of the quern $\Lambda \Theta 45$ (fig.20), which resembles the andesite from Aegina or other sites of Saronic Gulf, used especially in prehistoric times (Poupaki, 2014-15, pp. 14-15).

The scoriaceous lava of the hopper $\Lambda \Theta 1$ recalls the rock used for koan hopperrubbers and a rotary quern (Poupaki 2011b, nos. 31, 36, 38), which resembles the rock quarried in modern times at Pyrgi of Kos (Poupaki 2011b, p. 30).

All the millstones studied are dated in Hellenistic $(\Lambda \Theta 46, \Lambda \Theta 109, \Lambda \Theta 233)$ and Roman period $(\Lambda \Theta 225, \Lambda \Theta 111)$ based on their context, whereas several examples of olynthian mills and saddle querns cannot be securely dated, because they are surface findings $(\Lambda \Theta 1, \Lambda \Theta 113, \Lambda \Theta 127, \Lambda \Theta 219, \Lambda \Theta 224, \Lambda \Theta 226)$.

\section{Use of the querns from Agathonisi}

The millstones found were implements used for the processing of cereals and pulses. The most primitive querns, the saddle querns, are considered as inventions associated with the production of well-pulverized flour and they first appeared in ancient Egypt (Jasny 1950, p. 234). However, the olynthian mills improved and accelerated the processing of the grains. That is why they are considered as the first professional mills, used in bakeries (Poblome 2012, p. 85). The use of saddle querns for the murex processing at the prehistoric site of Mitrou, at eastern Lokris (Van de Moortel \& Zahou, 2011, p. 293), could lead us to the assumption that hopper-rubbers could also be efficient for such use, and consequently, that certain hopper-rubbers from Agathonisi could be associated with the purple production well-documented on site. The use of hoppers-rubbers, even for the crushing of ores at Lavrion (Ardaillon, 1897, pp. 62, 69, 92) proves that the olynthian querns were multifunctional implements and could also belong to industrial equipment. To that point we ought to stress that there are no remains of murex processing

Through it, it is common that cereals are funneled to the space between the two elements and then they are ground. The lower millstone and is fixed on a board (i.e., a table) beneath the querns, a structure that permits the steady rotation of the upper millstone. The spindle is held tight by a wooden frame fixed on the upper stone, whilst a wooden or metallic handle is fixed on its circumference, through the movement of which the circular movement of the quern is achieved: Poupaki (2014-15, pp. 20-21); Katerinopoulos et al. (2016, p.191); Poupaki (2017, pp. 84-86, with bibliography). 
on the grinding surfaces of the olynthian mills of Agathonisi; further examination and chemical analyses are indispensable to reach a conclusion.

The remarkable number of hopper-rubbers used in the fortified site of Agathonisi is a unique example in the Aegean. Ancient writers (e.g., Xenophon, The Anabasis, 1.5.5, Frontinus, Strategems 4.1.6) state that certain types of querns were in use by the soldiers, especially during their excursions, which should be lighter (molae manuariae) than the household implements and would provide the best solution for grinding cereals needed for nourishing a certain order of soldiers. For example, in Roman period, the smallest rotary querns were used in the order of 10 soldiers, the contubernium, whereas the bigger ones were in use in the order of 100 soldiers, the centurium (Child, 1943). According to Xenophon (The Anabasis, VII.I.37), barley flour was indispensable for the preparation of a soldier's meal, while Herodotus (Herodotus, History, 7.17) states that one or two

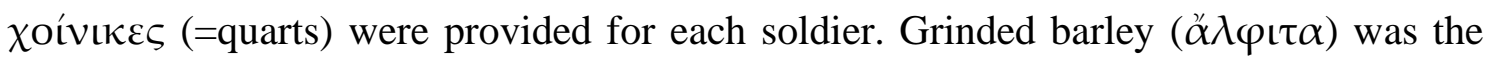
most preferred for a soldier's meal, especially during excursions, because it could be easily mixed up with water, oil, or wine, to prepare $\mu \tilde{\alpha} \zeta \alpha$ (resembled $\tau$ o porridge), which did not need further cooking (Thucydides, Historiae III.49.3). On the contrary, the flour needed for the kneading of bread should be pulverized (Jasny, 1950, pp. 244, 247; Amouretti, 1986, pp. 124-126).

The querns used by the army were carved in resistant volcanic material, which was originated from certain quarries ${ }^{27}$. In many excavated oppida of the Roman period across Europe (France, Spain, Germany) inscribed rotary querns had been found, which preserve the name of the order, where the soldiers belong (Jodry, 2010, pp. 107-108; Jodry, 2011b). Paradoxically, in Greece, little is known about the everyday utensils used by the soldiers. An olynthian mill had been found at the Ptolemaic military camp excavated in Koroni of eastern Attica (Vanderpool et al. 1962, 36, no. 33, pl. III), but no more examples from other excavated areas inhabited by soldiers had been recorded. That is why that the milling implements from Agathonisi are so important. The fact that the discovered querns belong to two basic types: the nisyrian products and the hopper-rubbers with the circular

\footnotetext{
${ }^{27}$ Querns carved in basaltic lava of Mayen in Eifel region (Germany) were of the highest quality and were exported in Central Europe during Roman period: Wefers (2011a); Mangartz (2006); Holtmeyer \& Wild (2014). However, there were several other quarries of various rocks suitable for millstones in the Roman era, which circulated all over Europe. In France, several quarries of millstones were opened in Alsace and in Lorraine: Boyer et al. (2006); Farget (2006); Jodry (2011a). However, La Salle quarries in Switzerland and Lovocise quarries in Tsechia were also exploited for mills: Anderson (2003); Jacottey, Anderson \& Jodry (2007); Wefers (2011b).
} 
hopper of unknown origin may indicate that they were the basic types used by certain orders of soldiers. The best quality of the rock, which would be resistant during the grinding without leaving grits in the flour, was the basic criterion for the certain choice of products (Poupaki, 2011a, vol. 1, pp. 226-227). It had been, therefore, well appreciated by the inhabitants of that fortified site on that small milesian island. It could be suggested that Miletus would be responsible for such provisions of that milesian fort, although the lack of relevant evidence does not allow further discussion.

\section{Question of insularity: isolation and connectivity}

The observed interrelations of the island with the opposite coasts do not necessarily mean that the island had been totally independent from milesian metropolis. On the contrary, even though Agathonisi is a rocky and remote island of the Aegean, it developed in antiquity economic activities as animal husbandry, mainly goat farming, fishery, and agriculture at the restricted fertile areas of the island. The recent findings from Kastraki added important evidence about the labors, which increased the income of the local population: beekeeping, honey production and production of purple-dye through the murex process were some of these tasks. The excavation provided also significant data about the occupation of the inhabitants with stone-carving. Local marble and limestone, but also imported volcanic rocks were used for manufacturing resistant vessels for everyday use. This may imply that the inhabitants of Kastraki settlement managed to combine their carving techniques with the ones adopted from other workshops of sculpture, so as to fulfill their needs and reduce the imports of high-priced products, as marble vases.The presence of specialized quarry-men and stone-carvers on the island can be corroborated by the existence of quarries of marble and limestone at Kavi (Triantafyllidis 2006, p. 185, note 50) and Kastraki (Kokkorou-Alevras et al. 2014, no. 63a), respectively.

The remains of the quarry at Kavi, northeast of Mount Kephala in the vicinity of the open-air Isis sanctuary, provide enough information about the extraction: quarried blocks are still visible, whereas quarried surfaces of the rock where plinths were detached from the maternal rock are quite impressive. On the rock surface four incised foot impressions, life-sized, had been recorded, among which one contains a dedicatory inscription APXE $\Lambda$ A (Triantafyllidis, 2006, pp. 185-186, fig. 9). Presumably, the quarry must be dated before the establishment of the cult on the site. That means that when the cult of Isis was initiated, the quarry had been probably left inactive. Future research, 
though, on the site will enlighten more aspects about its activity and the use of its quarried material.

The fortified site of Kastraki had been established on a rocky hill close to a secure natural harbor. The rock had been quarried for the formation of terraces, where the buildings of the fort had been erected. The remnants of the quarried rock are best preserved to the southern slopes of the hill, where important evidence about the quarrying techniques are observed: stepped extraction, wedge holes (sphenoid and rectangular-fig. 22), point marks, series of point marks (pointillé technique), quarrying trenches around the detached blocks, a pole-hole (fig. 23) used for the retention of the transferring sled on the sledding-path of the quarry, a circular print from a detached column drum, vertical trenches from the use of the pneumatic hammer, as recent quarrying by means of modern equipment was not avoided, etc. (Kokkorou - Alevras et al. 2014, no. 64). Basing on these quarrying traces a dating of the extraction activity before $4^{\text {th }}$ cent. BC can be suggested. The Kastraki quarry was probably opened for the construction of the local fort and it was probably abandoned when the site was inhabited. The study of the unfinished vessels found aids in confirming this assumption, given that the unfinished vase $\Lambda \Theta 230$ (fig. 5) carved in the local marble is well-dated in the early Hellenistic period, which means that the stone-carving activities took place before $275 \mathrm{BC}$ at the site.

Local limestone quarried on both extraction sites was of high quality and it served perfectly for the carving of vases. The local sculptors borrowed patterns and types from the most popular marble workshops of the Hellenistic and Roman times, as it is attested by the study of their counterparts. We can suppose that either the local carvers were experienced craftsmen, either that foreign specialists on carving techniques spent some time on the island and transmitted their knowledge to the locals. The latest can be justified by the strong connection of the island with the milesian metropolis, where important quarries were active since Archaic times, as the Heracleia on Latmos major quarries (Peshlow-Bindokat, 1981 and 1996; Herda et al., 2019), whose exploitation consisted a profitable activity throughout the Archaic and Classical period for Miletos supplying high-quality marble for major buildings (e.g., the sanctuary of Apollo at Didyma) (Attanasio, Brilli \& Ogle, 2006, pp. 190-198).

The occurrence of imported artifacts among the studied material from Kastraki excavation implies, besides the strong connectivity of the island with Miletos, the merchandise exchange with other cities of Asia Minor, as well as with other islands, not only the closest ones, like Samos, but also certain further islands of the Dodecanese, like 
Kos, Nisyros, and Rhodes and Saronic Gulf. To these conclusions we come basing on the detection of the artifacts' stone origin. The lack of archaeometric methods applied on samples of stone samples from the artifacts forced us to rely only on the visual observation. In particular, the vase $\Lambda \Theta 228$ is thought to be samian because it is carved in samian limestone, like an aeginetan parallel, too. The generalized use of samian limestone in architecture ${ }^{28}$ and sculpture ${ }^{29}$ since the Archaic period supports the idea of carving vases, too. The strong affiliation of the rock used for the vase from Agathonisi with the rock quarried from the underground quarries of southern Samos points out that the vase was probably carved in Samian workshop, which was active even since Archaic times, but continued their activity during the Hellenistic period, as the Agathonisi vase $\Lambda \Theta 60$ proves, and even later. The probable use of nisyrian lava for the high stemmed ő $\lambda \mu o \varsigma$ and most of the olynthian mills from Kastraki excavation indicates the circulation of the nisyrian products, at least, during the Hellenistic period. A recent study shed light on the activity of the nisyrian lava workshop, which was a unique production unit of

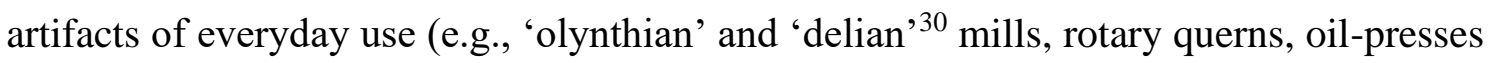
equipment, mortars et.c.) in the Aegean from the $4^{\text {th }}$ century BC onwards (Poupaki, in print c). Minor imports of olynthian mills from Kos or Aegina / Saronic Gulf or elsewhere imply that the small island was accessible from remote islands, even outside the Dodecanese. In the absence of archaeometric analyses, no more conclusions can be drawn. It is also impressive, that a half-finished mortar was carved in a rock reminiscent of koan rhyolite, but more provenances could be probable for its rock. However, it is quite important to observe that the foreign rocks had been transferred roughly finished and that their final formation was completed at the destination place ${ }^{31}$.

\footnotetext{
28 That limestone is attested at the double colonnade of the Dipteros II temple in Heraion of Samos-of the early $6^{\text {th }}$ cent. BC: Hellner (2001, pp. 7-8, note 8, p. 135, note 135); Osborne (2003, p. 99, fig. 103b). The samian limestone was also used in Roman period for the pavement of the the Sacred Way and for the Roikos altar: Tziligkaki \& Stamatakis (2018, pp. 177-178).

${ }^{29}$ In Samos, Archaic stelae were carved in soft, porous limestone, probably local: Tsakos \& ViglakiSofianou (2012, p. 222).

${ }^{30}$ Delian mills are not hand-mills, but they were operated by a donkey or a slave due to a complex metallic frame: Poupaki (2017, nos. K65-K71).

${ }^{31}$ That is the case for the most stone-producing places, where rough blocks of stone were transported to the places of order, where they were shaped to get the final form. For instance, on the proconnesian products which were carried unfinished to Kos: Poupaki (2011a, vol. 1, 192-194).
} 


\section{Conclusions}

To sum up with the current presentation, it was briefly argued that all these stone artifacts of lesser value, as stone vases, and querns, bring information on the ancient history of Agathonisi. Basing on this subsidiary study, we may assume that the intercommunications of that island with the surrounding and most remote islands or Asia Minor proved to be valuable for the formation of its cultural identity. Meanwhile, its population managed to exploit local natural resources and to assimilate the foreign influences by producing native products of high quality. During the archaeological research, the minor findings confirm that several daily activities were adopted by the local population, e.g., fishing, beekeeping, weaving, and pottery production (Triantafyllidis, 2015, 95). To these labors, the carving of vessels using the local limestone quarried nearby can be added. Future archaeological research at Kastraki will complete this preliminary report on the productive activities of its inhabitants, which were not only military, but also "agroeconomic and commercial" (Triantafyllidis, 2015, p. 103), and influenced the political identity of the small island.

\section{Acknowledgements}

I would like to thank deeply Pavlos Triantafyllidis, who granted me with the permission of this study, and his support during my study at Agathonisi. I am also indebted to Marigo Kantzillieri for the revision of my english manuscript.

Article received in: 07/03/2021

Approved in: 21/03/2021 


\section{TABLE 1}

\begin{tabular}{|c|c|c|}
\hline $\begin{array}{l}\text { CATALOGUE } \\
\text { NUMBER }\end{array}$ & DESCRIPTION & DIMENSIONS $^{32}$ \\
\hline & VASES & \\
\hline$\Lambda \Theta 229$ (fig. 4) & $\begin{array}{l}\text { Fragmented mortar carved } \\
\text { in local grey marble. } \\
\text { Prehistoric. }\end{array}$ & ht 5.5, dp $1.5-4$, d 18 \\
\hline$\Lambda \Theta 228$ (fig. 8) & $\begin{array}{l}\text { Two handled, shallow } \\
\text { bowl carved in samian } \\
\text { yellowish sandstone } \\
\text { (completed). Late Archaic- } \\
\text { Classical. }\end{array}$ & $\begin{array}{l}\text { ht } 7 \text {, rim } d 23 \text {, base } d 12 \text {, } \\
\text { handle } \operatorname{dim} 5.5 \times 1 \times 2 \text {, base } \\
\text { ht } 0.7 \text {, rim th } 1.5 \text {, wall th } \\
1.5-2.5 \text {, bottom th } 2.5\end{array}$ \\
\hline$\Lambda \Theta 60$ (fig. 9) & $\begin{array}{l}\text { Two handled mortar carved } \\
\text { in samian yellowish } \\
\text { sandstone. Hellenistic. }\end{array}$ & $\begin{array}{l}\text { Preserved ht } 6.5 \text {, rim } \mathrm{d} 25, \\
\text { base d } 45 \text {, handle dim } 5.6 \times \\
1.2 \times 1.8 \text {, base ht } 1 \text {, wall th } \\
1.8-2.3 \text {, bottom th } 1.3- \\
2.5\end{array}$ \\
\hline$\Lambda \Theta 230$ (fig. 5) & $\begin{array}{l}\text { Fragmented unfinished } \\
\text { mortar (holmos) carved in } \\
\text { local white-greyish } \\
\text { limestone. Hellenistic. }\end{array}$ & $\begin{array}{l}\text { ht } 16.5-19.5, \operatorname{rim} \mathrm{d} 30 \text {, } \\
\text { rim th } 3 \text {, wall th } 5.5-6.5, \mathrm{dp} \\
15 \text {, bottom d } 20\end{array}$ \\
\hline$\Lambda \Theta 42$ (fig. 6) & $\begin{array}{l}\text { Fragmented unfinished } \\
\text { mortar (holmos) carved in } \\
\text { white-greyish local marble. } \\
\text { Hellenistic. }\end{array}$ & $\begin{array}{l}\text { preserved ht } 18, \text { rim d } 30 \text {, } \\
\text { rim th } 2.5 \text {, wall th } 8 \text {, bottom } \\
\text { th } 2-4\end{array}$ \\
\hline$\Lambda \Theta 227 \alpha \beta$ (fig. 7) & $\begin{array}{l}\text { Unfinished mortar with } \\
\text { spout carved in white- }\end{array}$ & $\begin{array}{l}\text { ht } 6 \text {, rim th } 2-4 \text {, wall th } 2.3 \\
-2.9 \text {, spout } \operatorname{dim} 10 \times 12 \text { x } 6 \\
\times 3 \text {, spout dp } 5, \operatorname{dim} 27 / 34\end{array}$ \\
\hline
\end{tabular}

${ }^{32}$ All the dimensions are in centimeters. Abbreviations:

Dim=dimension, ht=height, $d=$ diameter, l=length, $w=$ width, th=thickness, $d p=$ depth 
Eirene Poupaki, Stone Artifacts from Agathonisi...

\begin{tabular}{|c|c|c|}
\hline & $\begin{array}{l}\text { greyish local marble } \\
\text { (completed). Hellenistic. }\end{array}$ & \\
\hline$\Lambda \Theta 234$ & $\begin{array}{l}\text { Unfinished mortar carved } \\
\text { in grey rhyolite, probably } \\
\text { from Kos. Hellenistic. }\end{array}$ & $\begin{array}{l}\text { ht } 23 \text {, rim th } 10, \text { bottom th } \\
13\end{array}$ \\
\hline$\Lambda \Theta 102 \alpha \beta$ & $\begin{array}{l}\text { Fragmented mortar carved } \\
\text { in grey marble with white } \\
\text { veins. Hellenistic. }\end{array}$ & $\begin{array}{l}\text { rim th } 3.5 \text {, wall th } 3.5-4.5 \text {, } \\
\text { handle } \operatorname{dim} 8.5 \times 6.5 \times 4.5\end{array}$ \\
\hline \multirow[t]{2}{*}{$\begin{array}{l}\Lambda \Theta 44+\Lambda \Theta 62 \alpha \beta \text { (fig. } \\
12 \text { ) }\end{array}$} & $\begin{array}{l}\text { High stemmed mortar } \\
\text { (completed) carved in grey } \\
\text { vesicular lava, probably } \\
\text { from Nisyros. Hellenistic. }\end{array}$ & $\begin{array}{l}\text { Wall th } 4.5-8, \text { base } \mathrm{d} 30 \text {, } \\
\text { base ht } 18, \text { bottom th } 15\end{array}$ \\
\hline & PESTLES & \\
\hline$\Lambda \Theta \mathbf{1 0 7}$ (fig. 13) & $\begin{array}{l}\text { Fragmented conical marble } \\
\text { pebble }\end{array}$ & $\begin{array}{l}\text { ht } 6 \text {, grinding surface d } 5.7 \\
-6\end{array}$ \\
\hline$\Lambda \Theta 231$ (fig. 13) & $\begin{array}{l}\text { Fragmented trapezoidal } \\
\text { marble pebble }\end{array}$ & ht $9.5, \operatorname{dim} 5 \times 5 / 8 \times 8$ \\
\hline$\Lambda \Theta 237$ & $\begin{array}{l}\text { Fragmented elongated } \\
\text { marble pebble }\end{array}$ & $\begin{array}{l}\text { Preserved ht } 4, \text { preserved d } \\
2\end{array}$ \\
\hline$\Lambda \Theta 235$ (fig. 14) & $\begin{array}{l}\text { Fragmented pestle carved } \\
\text { in non-local purplish } \\
\text { volcanic rock }\end{array}$ & $\begin{array}{l}\text { Preserved ht } 3 \text {, preserved d } \\
3\end{array}$ \\
\hline$\Lambda \Theta 65$ (fig. 15) & $\begin{array}{l}\text { Finger-pestle carved in } \\
\text { fine-grained white marble. } \\
\text { Hellenistic }\end{array}$ & $19, \mathrm{w} 3-4$, th $2.5-4.2$ \\
\hline \multirow[t]{2}{*}{$\Lambda \Theta 238$ (fig. 15) } & $\begin{array}{l}\text { Finger-pestle carved in } \\
\text { white-greyish } \\
\text { Hellenistic }\end{array}$ & Ht $4, \mathrm{~d} 2.5$ \\
\hline & SADDLE QUERNS & \\
\hline$\Lambda \Theta 103$ (fig. 16) & $\begin{array}{l}\text { Fragmented saddle quern } \\
\text { carved in grey vesicular } \\
\text { lava. Prehistoric }\end{array}$ & 110, preserved th 13.5, th 6 \\
\hline
\end{tabular}




\begin{tabular}{|c|c|c|}
\hline$\Lambda \Theta 115$ (fig. 16) & $\begin{array}{l}\text { Fragmented saddle quern } \\
\text { carved in grey vesicular } \\
\text { lava. Prehistoric }\end{array}$ & $\begin{array}{l}\text { ht } 4.5-6 \text {, preserved } 114.5 \text {, } \\
\text { maximum w } 17.5\end{array}$ \\
\hline$\Lambda \Theta 126$ (fig. 16) & $\begin{array}{l}\text { Fragmented saddle quern } \\
\text { carved in grey vesicular } \\
\text { lava. Prehistoric }\end{array}$ & $\begin{array}{l}\text { ht } 5.8, \text { preserved } 18, \\
\text { maximum w } 13\end{array}$ \\
\hline \multirow[t]{2}{*}{$\Lambda \Theta 226$ (fig. 16) } & $\begin{array}{l}\text { Fragmented saddle quern } \\
\text { carved in grey vesicular } \\
\text { lava. Prehistoric }\end{array}$ & $\begin{array}{l}\text { ht } 5.5 \text {, preserved } 19.5 \text {, } \\
\text { maximum w } 14.5\end{array}$ \\
\hline & GRINDER & \\
\hline \multirow[t]{2}{*}{$\Lambda \Theta 43$ (fig. 17) } & $\begin{array}{l}\text { Grinder carved in grey } \\
\text { vesicular lava. Prehistoric }\end{array}$ & $\begin{array}{l}\text { ht } 7 \text {, grinding surface d 5.9- } \\
7.5\end{array}$ \\
\hline & HOPPER-RUBBERS & \\
\hline$\Lambda \Theta 46$ & $\begin{array}{l}\text { Fragmented lower } \\
\text { olynthian mill carved in } \\
\text { grey vesicular lava, } \\
\text { probably from Nisyros. } \\
\text { Hellenistic. }\end{array}$ & ht $4.6-5.3$, side 116.5 \\
\hline$\Lambda \Theta 109$ & $\begin{array}{l}\text { Fragmented lower } \\
\text { olynthian mill carved in } \\
\text { grey vesicular lava, } \\
\text { probably from Nisyros. } \\
\text { Hellenistic. }\end{array}$ & ht $2.5-3.1$ \\
\hline$\Lambda \Theta 112$ & $\begin{array}{l}\text { Fragmented lower } \\
\text { olynthian mill carved in } \\
\text { grey vesicular lava, } \\
\text { probably from Nisyros. } \\
\text { Hellenistic. }\end{array}$ & ht $3.5-4.1$ \\
\hline$\Lambda \Theta 110$ (fig. 21) & $\begin{array}{l}\text { Fragmented } \\
\text { olynthian mill carved in } \\
\text { grey volcanic } \\
\text { unknown } \\
\text { Hellenistic. }\end{array}$ & ht 6 , sides 114 and 18 \\
\hline
\end{tabular}


Eirene Poupaki, Stone Artifacts from Agathonisi...

\begin{tabular}{|c|c|c|}
\hline$\Lambda \Theta 222$ (fig. 21) & $\begin{array}{l}\text { Fragmented } \\
\text { olynthian mill carved in } \\
\text { grey volcanic rock of } \\
\text { unknown } \\
\text { Hellenistic. }\end{array}$ & $\begin{array}{l}\text { ht } 3.5-5.5 \text {, sides } 117.5 \text { and } \\
22\end{array}$ \\
\hline$\Lambda \Theta 217$ & $\begin{array}{l}\text { Fragmented upper } \\
\text { olynthian mill carved in } \\
\text { grey vesicular lava, } \\
\text { probably from Nisyros. } \\
\text { Hellenistic. }\end{array}$ & ht $9-11.5$, side $19-11.5$ \\
\hline$\Lambda \Theta 218$ (fig. 18) & $\begin{array}{l}\text { Fragmented upper } \\
\text { olynthian mill carved in } \\
\text { grey vesicular lava, } \\
\text { probably from Nisyros. } \\
\text { Hellenistic. }\end{array}$ & $\begin{array}{l}\text { ht } 11 \text {, side } 112-13.5 \text {, rim } \\
\text { th } 3\end{array}$ \\
\hline$\Lambda \Theta 219$ (fig. 18) & $\begin{array}{l}\text { Fragmented upper } \\
\text { olynthian mill carved in } \\
\text { grey vesicular lava, } \\
\text { probably from Nisyros. } \\
\text { Hellenistic. }\end{array}$ & $\begin{array}{l}\text { ht } 10,5 \text {, sides } 19.5 \text { and } 12 \text {, } \\
\text { rim th } 4-6\end{array}$ \\
\hline$\Lambda \Theta 220$ (fig. 18) & $\begin{array}{l}\text { Fragmented upper } \\
\text { olynthian mill carved in } \\
\text { grey vesicular lava, } \\
\text { probably from Nisyros. } \\
\text { Hellenistic. }\end{array}$ & $\begin{array}{l}\text { ht } 13.2-15.3, \text { sides } 119- \\
22 / 23-25.5, \text { rim th } 3-3.5 \\
/ 5-5.5, \text { slot ht } 3\end{array}$ \\
\hline$\Lambda \Theta 223$ & $\begin{array}{l}\text { Fragmented upper } \\
\text { olynthian mill carved in } \\
\text { grey vesicular lava, } \\
\text { probably from Nisyros. } \\
\text { Hellenistic. }\end{array}$ & $\begin{array}{l}\text { ht } 4.6-8 \text {, sides } 121.5-23 \\
\text { and } 17-17.5\end{array}$ \\
\hline$\Lambda \Theta 221$ (fig. 19) & $\begin{array}{l}\text { Fragmented upper } \\
\text { olynthian mill carved in }\end{array}$ & $\begin{array}{l}\text { ht } 8.5-9.8 \text {, sides } 118.5-28 \\
\text { and } 11-13 \text {, rim th } 7 \text { and } 3.5\end{array}$ \\
\hline
\end{tabular}




\begin{tabular}{|c|c|c|}
\hline & $\begin{array}{l}\text { grey rhyolite probably } \\
\text { from Kos. Hellenistic. }\end{array}$ & \\
\hline$\Lambda \Theta 45$ (fig. 20) & $\begin{array}{l}\text { Fragmented upper } \\
\text { olynthian mill carved in } \\
\text { grey andesite from Aegina } \\
\text { or other sites of Saronic } \\
\text { Gulf. Hellenistic. }\end{array}$ & $\begin{array}{l}\text { ht } 6-9.5 \text {, hopper dp } 2- \\
2.5 \text {, socket } \operatorname{dim} 1.5 \times 1.7 \times \\
3, \text { rim th } 4.5-5.5\end{array}$ \\
\hline$\Lambda \Theta 113$ & $\begin{array}{l}\text { Fragmented upper } \\
\text { olynthian mill carved in } \\
\text { grey vesicular lava, } \\
\text { probably from Nisyros. } \\
\text { Hellenistic-Roman. }\end{array}$ & $\begin{array}{l}\text { ht } 8.5 \text {, sides } 119 \text { and } 2.5 \text {, } \\
\text { slot } \operatorname{dim} 1 \times 2.5 \times 1 \text {, rim th } \\
5.5\end{array}$ \\
\hline$\Lambda \Theta 1$ & $\begin{array}{l}\text { Fragmented upper } \\
\text { olynthian mill carved in } \\
\text { black scoriaceous lava of } \\
\text { unknown origin. } \\
\text { Hellenistic - Roman. }\end{array}$ & $\begin{array}{l}\text { ht } 9.5 \text {, sides } 15-6.5 \text { and } \\
5.5-7.5 \text {, slot } \operatorname{dim} 1.5 \times 1.5 \\
\times 3.5 \text {, rim th } 10\end{array}$ \\
\hline$\Lambda \Theta 127$ & $\begin{array}{l}\text { Fragmented lower } \\
\text { olynthian mill carved in } \\
\text { grey vesicular lava, } \\
\text { probably from Nisyros. } \\
\text { Hellenistic - Roman. }\end{array}$ & ht $5-5.5$, side 112.5 \\
\hline$\Lambda \Theta 224$ (fig. 21) & $\begin{array}{l}\text { Fragmented lower } \\
\text { olynthian mill carved in } \\
\text { grey volcanic rock of } \\
\text { unknown origin. } \\
\text { Hellenistic - Roman. }\end{array}$ & $\begin{array}{l}\text { ht } 5.6-7.5 \text {, sides } 121 / 22.5 \\
\text { and } 12.5\end{array}$ \\
\hline$\Lambda \Theta 111$ & $\begin{array}{l}\text { Fragmented upper } \\
\text { olynthian mill carved in } \\
\text { grey vesicular lava, } \\
\text { probably from Nisyros. } \\
\text { Roman. }\end{array}$ & $\begin{array}{l}\text { ht } 13-15 \text {, side } 119, \text { w rim } \\
3 \text { / } 8\end{array}$ \\
\hline
\end{tabular}


Eirene Poupaki, Stone Artifacts from Agathonisi...

\begin{tabular}{|c|c|c|}
\hline$\Lambda \Theta 225$ & $\begin{array}{l}\text { Fragmented lower } \\
\text { olynthian mill carved in } \\
\text { grey vesicular lava, } \\
\text { probably from Nisyros. } \\
\text { Roman. }\end{array}$ & ht 9 , side 119 \\
\hline
\end{tabular}


Mare Nostrum, ano 2021, v. 12, n. 2

\section{FIGURES}

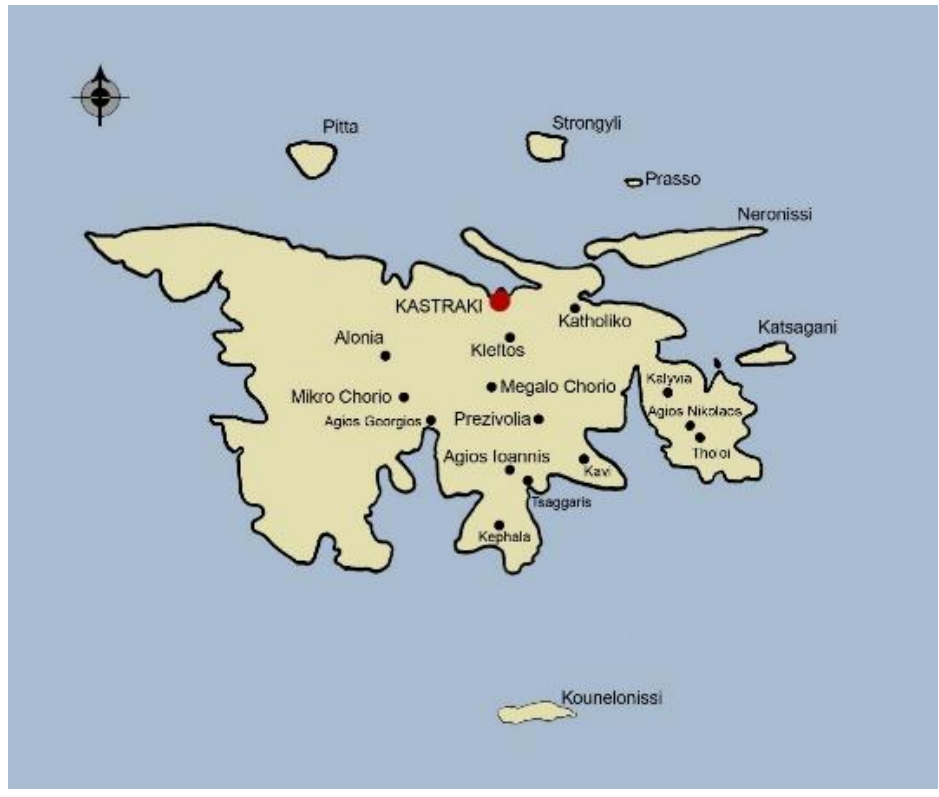

Figure 1: Map of Agathonisi (map by Pavlos Triantafyllidis).

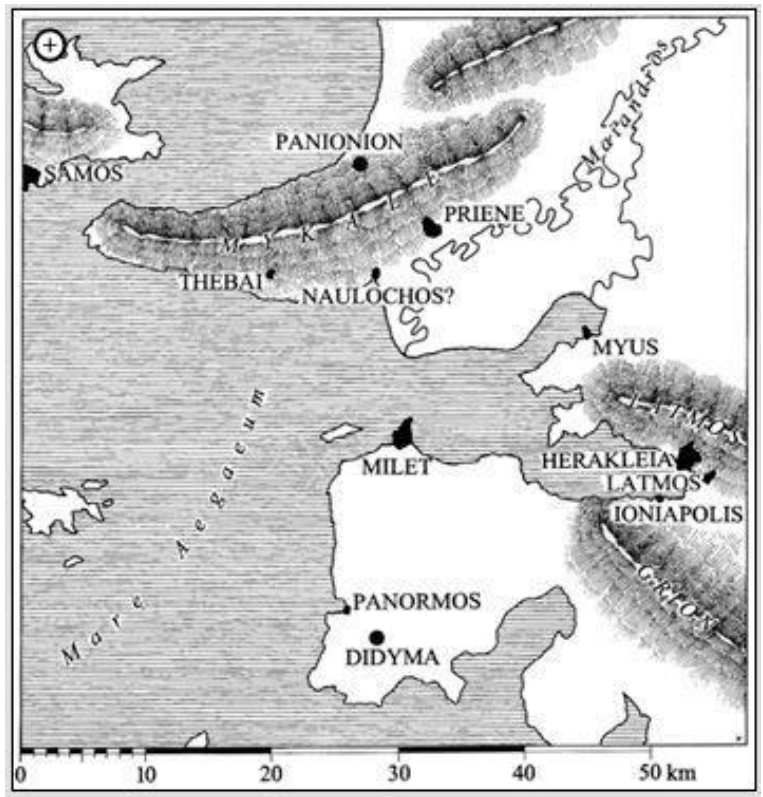

Figure 2: Map of Miletos and the milesian islands during the Classical antiquity (drawing by Jörg Denkinger, retrieved at: http://www.latmosfelsbilder.de/0203.php?l=eng).

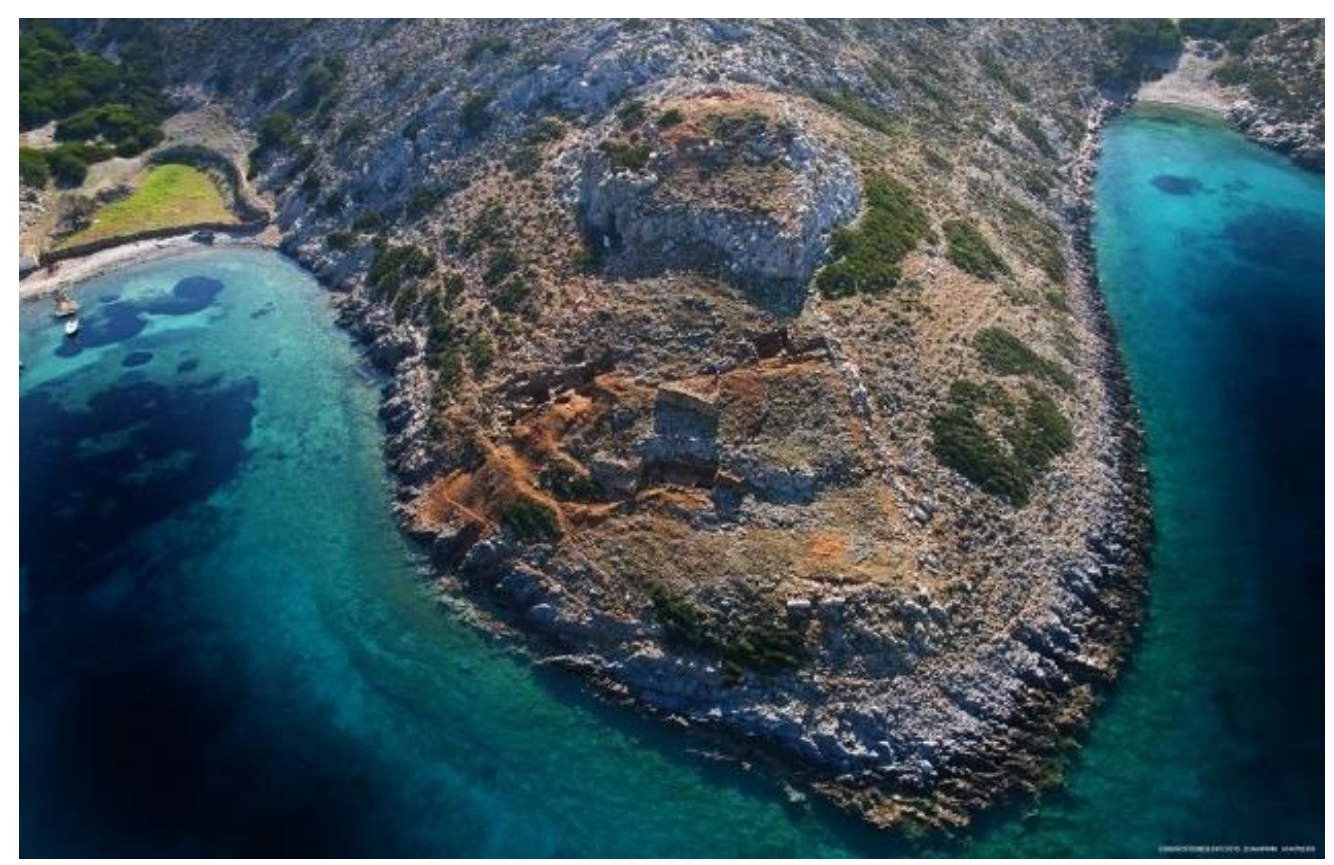

Figure 3: Aerial photo of Kastraki fort in Agathonisi (photo by Pavlos Triantafyllidis). 
Eirene Poupaki, Stone Artifacts from Agathonisi...

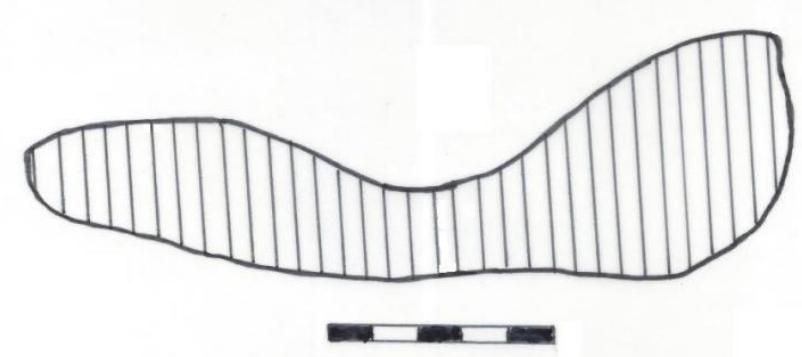

Figure 4: Section of the mortar $\Lambda \Theta 229$ (drawing by Eirene Poupaki).

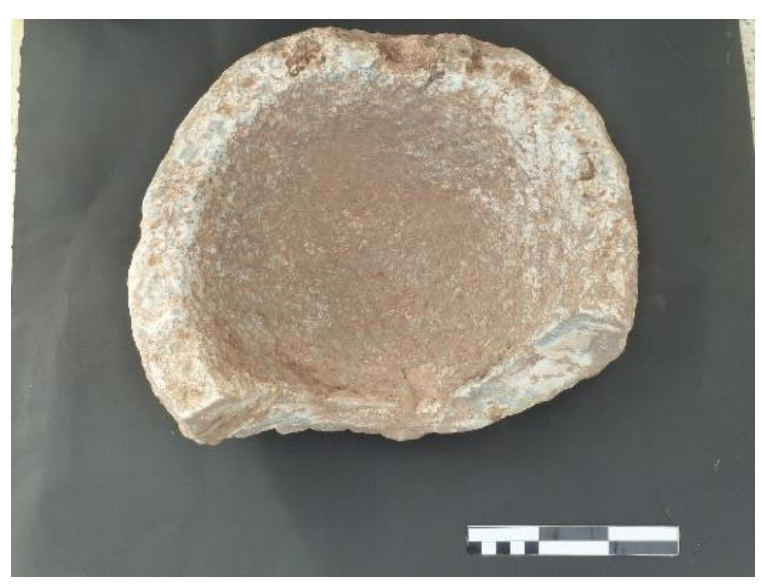

Figure 5: Unfinished mortar $\Lambda \Theta 230$ (photo by Eirene Poupaki).

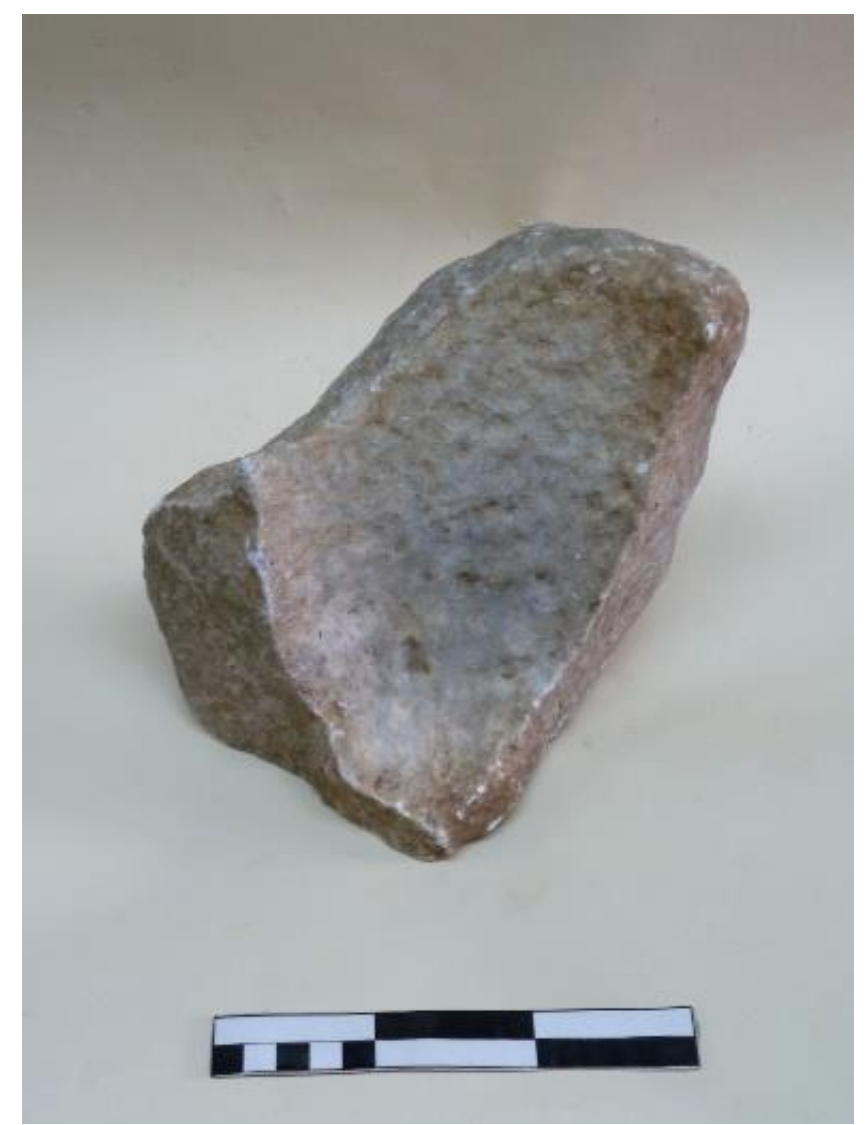

Figure 6: Unfinished mortar $\Lambda \Theta 42$ (photo by Eirene Poupaki). 
Mare Nostrum, ano 2021, v. 12, n. 2

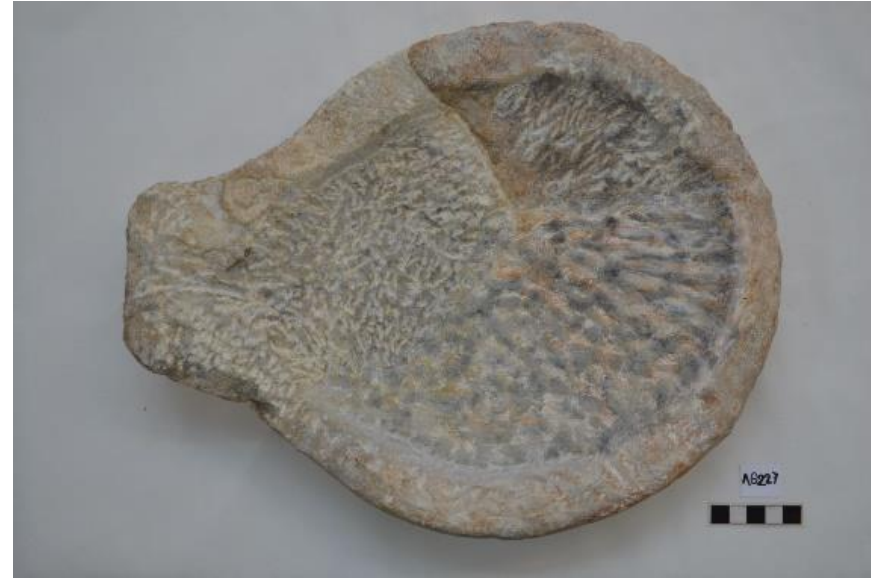

Figure 7: Unfinished mortar with spout $\Lambda \Theta 227$ (the vase is composed by two fragments and it is completed, photo by Pavlos Triantafyllidis).

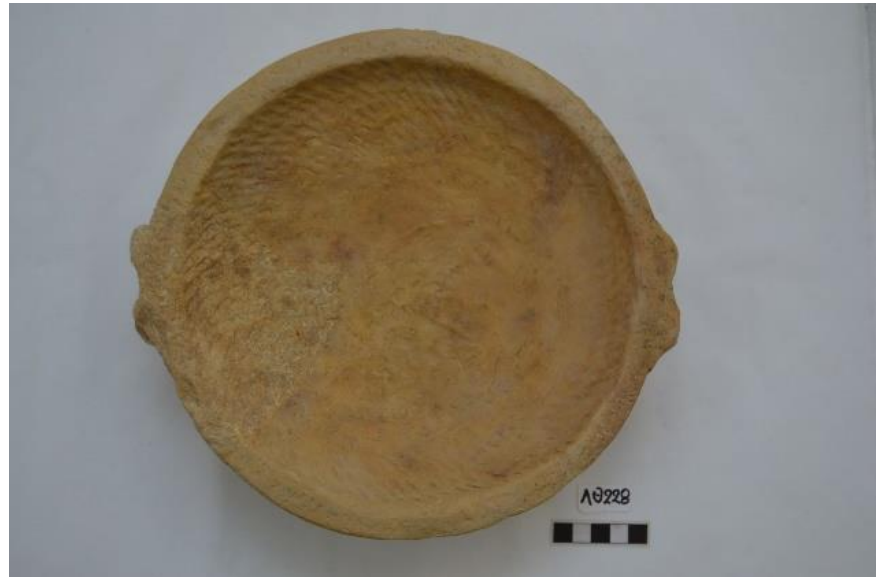

Figure 8: Unfinished two handled bowl $\Lambda \Theta 228$ (the vase is completed, photo by Pavlos Triantafyllidis).

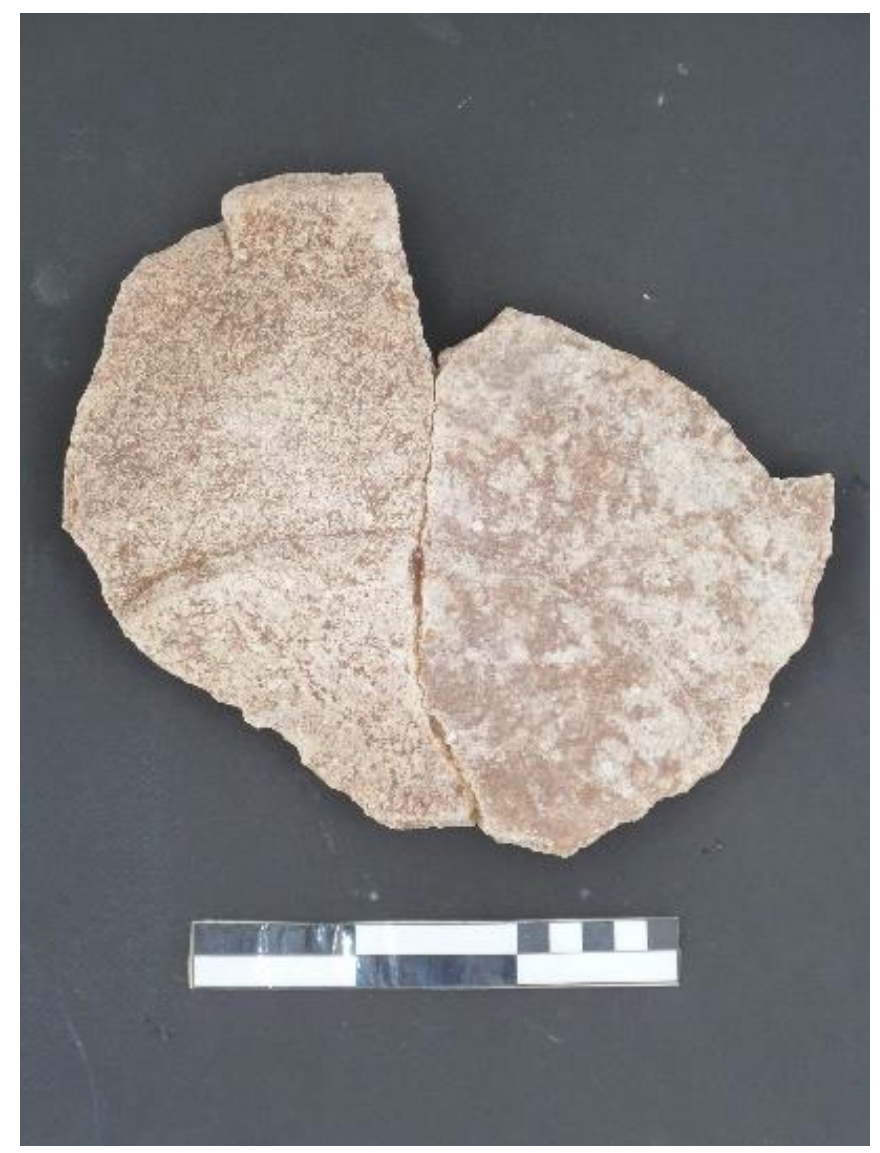

Figure 9: Fragmented bowl $\Lambda \Theta 42$ (photo by Eirene Poupaki). 


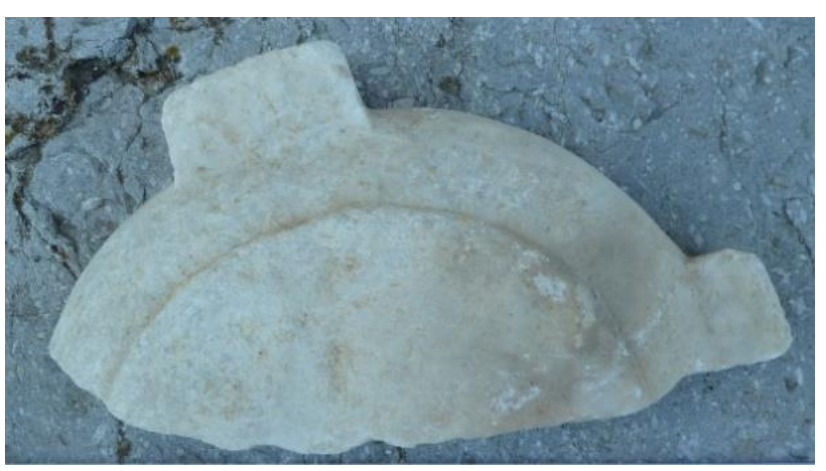

Figure 10: Fragmented bowl from Kos (photo by Eirene Poupaki).

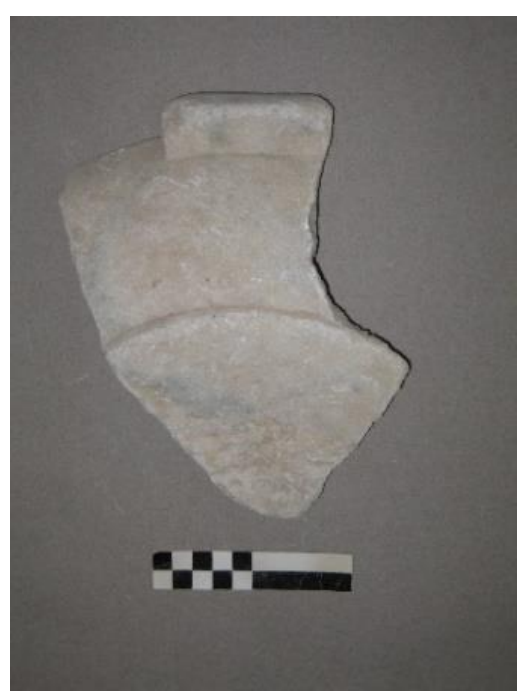

Figure 11: Fragmented bowl from Kos (photo by Eirene Poupaki).

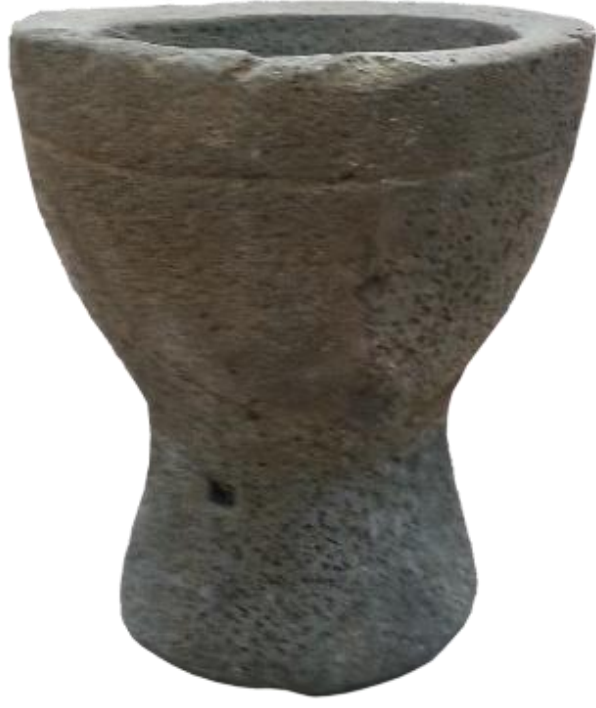

Figure 12: High stemmed holmos (the vase is composed by two fragments and it is completed, photo by Pavlos Triantafyllidis). 

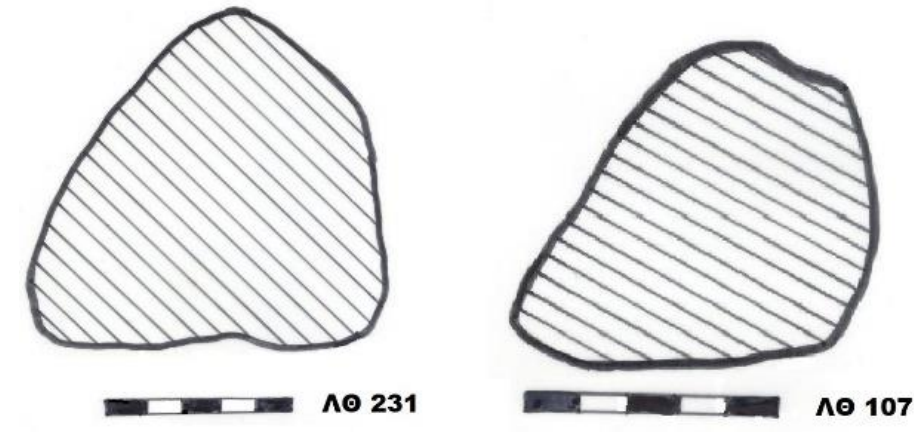

Figure 13: Sections of two pestles $\Lambda \Theta 107$ and $\Lambda \Theta 231$ (drawing by Eirene Poupaki).

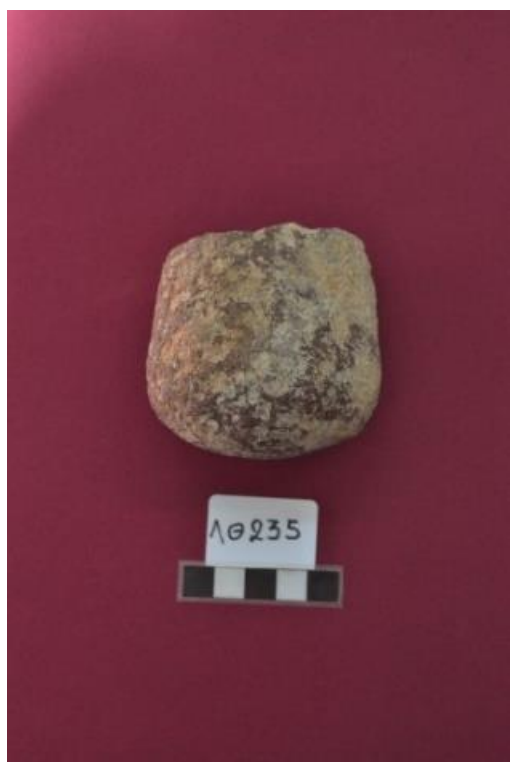

Figure 14: Fragment of a pestle $\Lambda \Theta 235$ (photo by Eirene Poupaki).

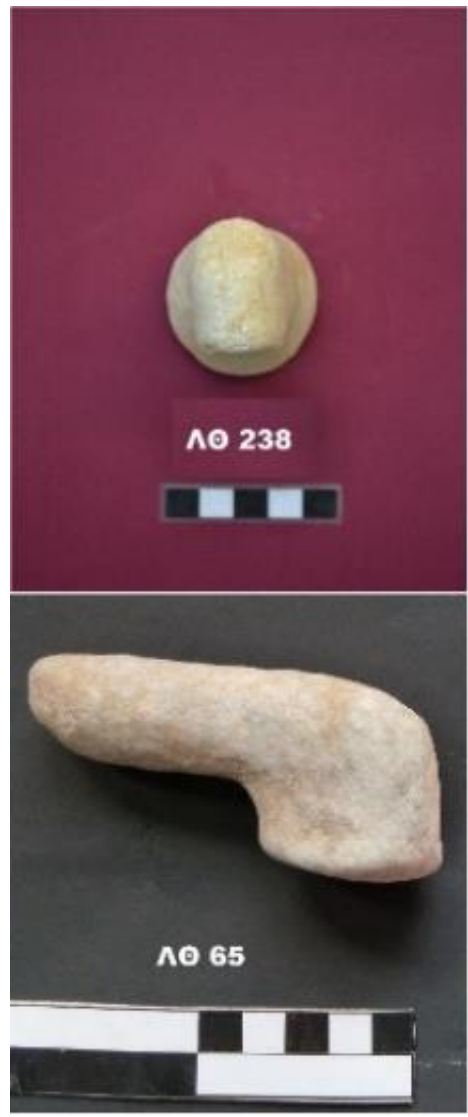

Figure 15: Fragmented finger-pestles $\Lambda \Theta 238$ and $\Lambda \Theta 65$ (photo by Eirene Poupaki). 
Eirene Poupaki, Stone Artifacts from Agathonisi...

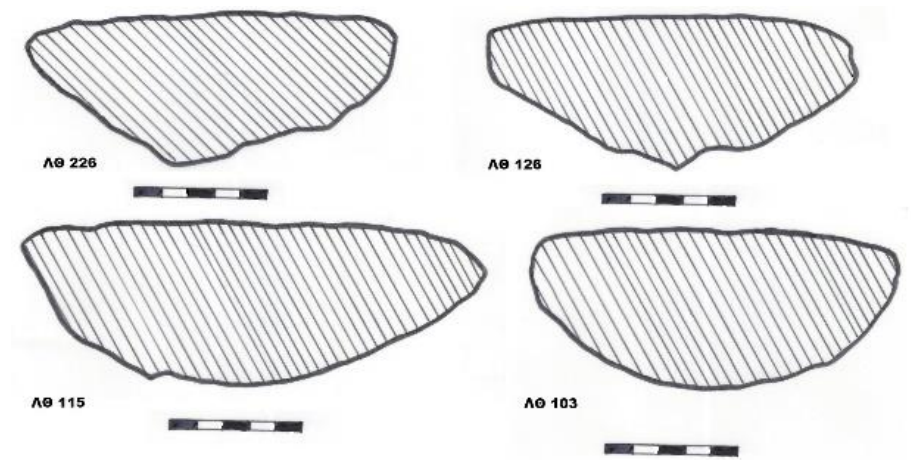

Figure 16: Sections of four saddle querns $\Lambda \Theta 103, \Lambda \Theta 115, \Lambda \Theta 126$, and $\Lambda \Theta 226$ (drawing by Eirene Poupaki).

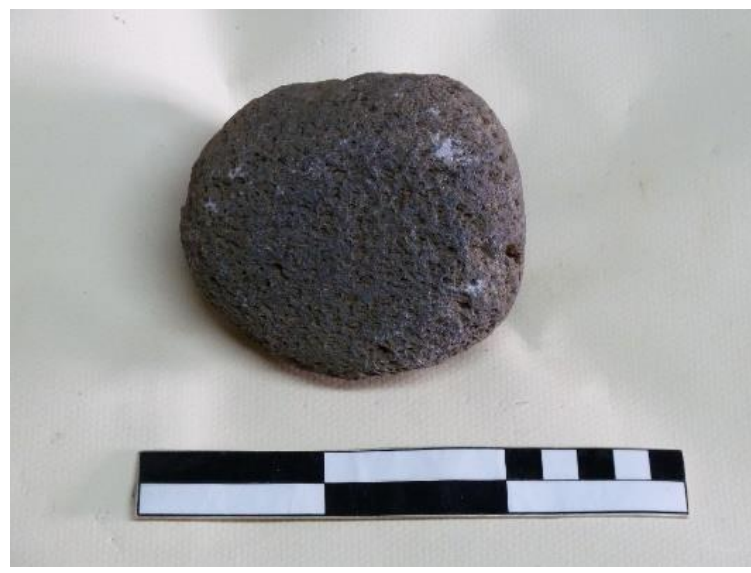

Figure 17: Grinder $\Lambda \Theta 43$ (photo by Eirene Poupaki).

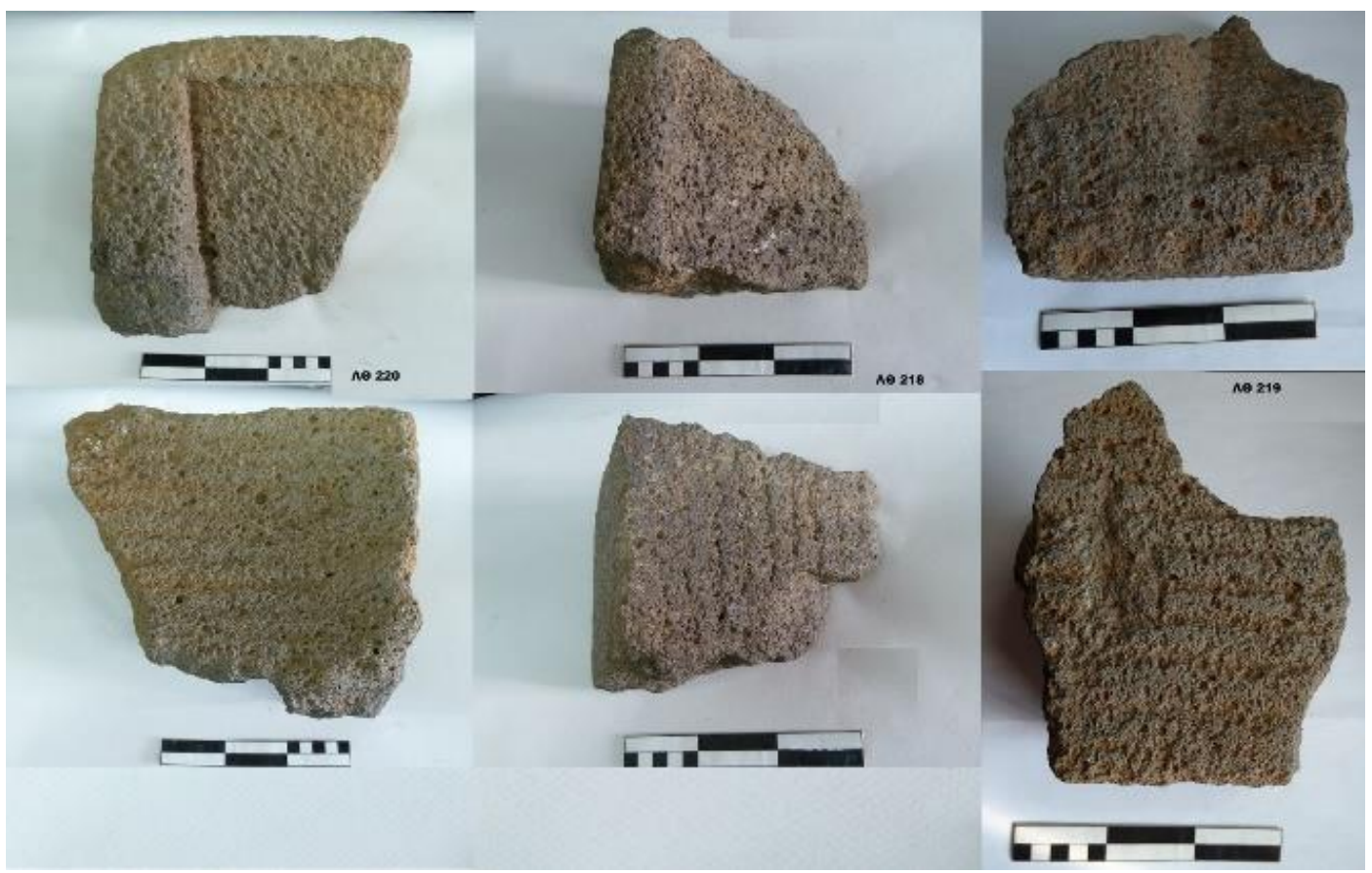

Figure 18: Fragments of olynthian querns $\Lambda \Theta 218, \Lambda \Theta 219$ and $\Lambda \Theta 220$ (photo by Eirene Poupaki). 
Mare Nostrum, ano 2021, v. 12, n. 2
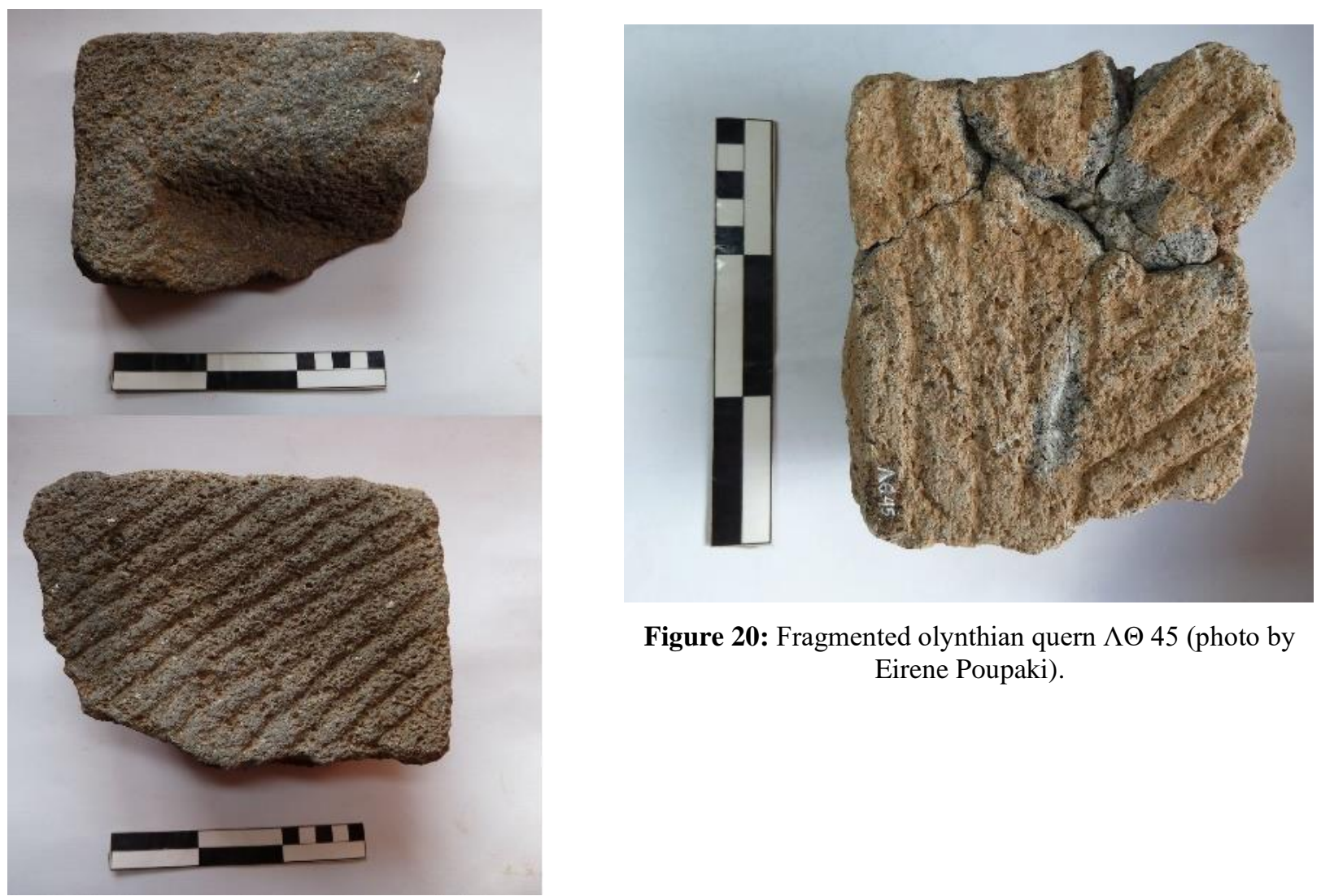

Figure 20: Fragmented olynthian quern $\Lambda \Theta 45$ (photo by Eirene Poupaki).

Figure 19: Fragment of olynthian quern $\Lambda \Theta 221$ (photo by Eirene Poupaki).

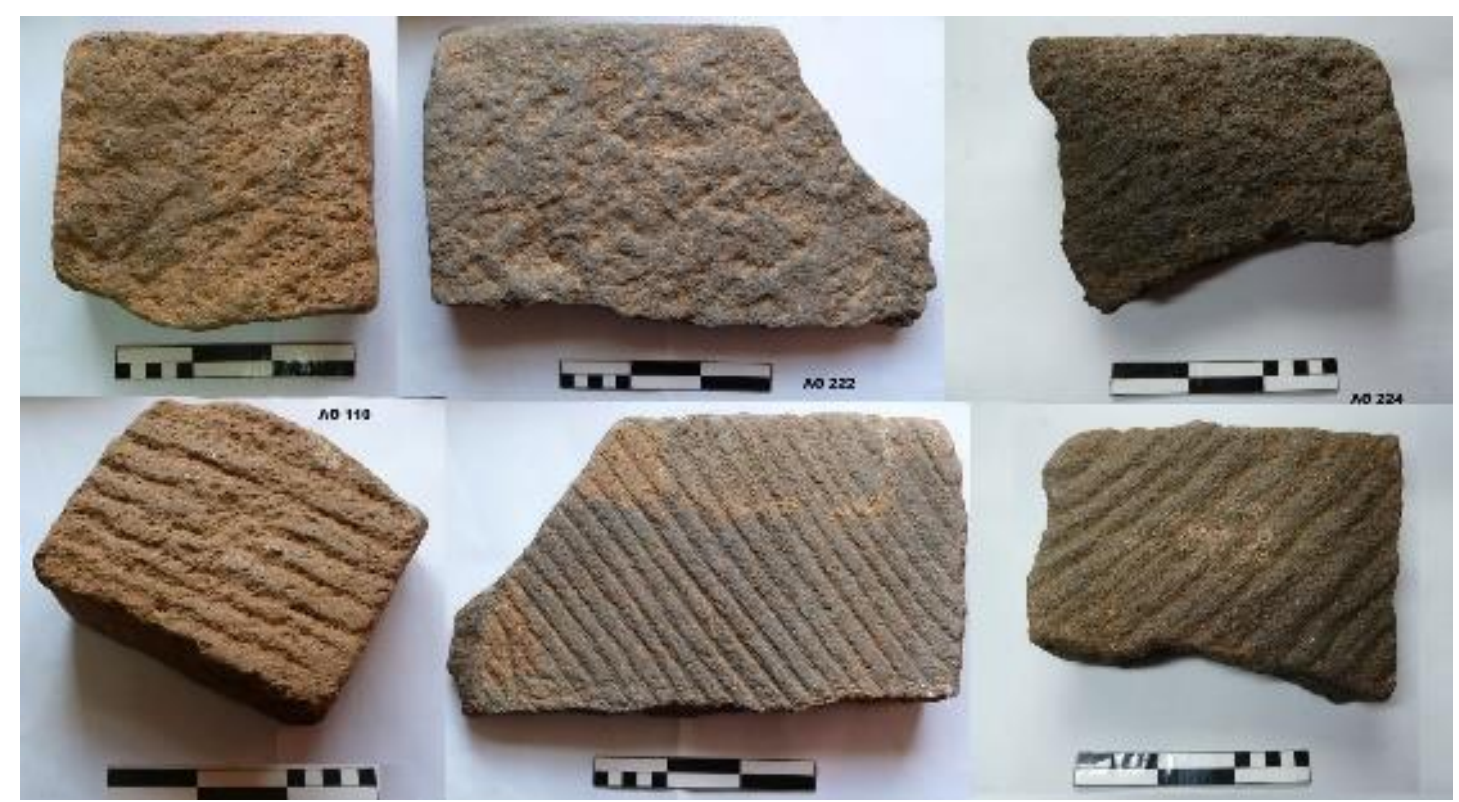

Figure 21: Fragments of olynthian querns $\Lambda \Theta 110, \Lambda \Theta 222$ and $\Lambda \Theta 224$ (photo by Eirene Poupaki). 
Eirene Poupaki, Stone Artifacts from Agathonisi...

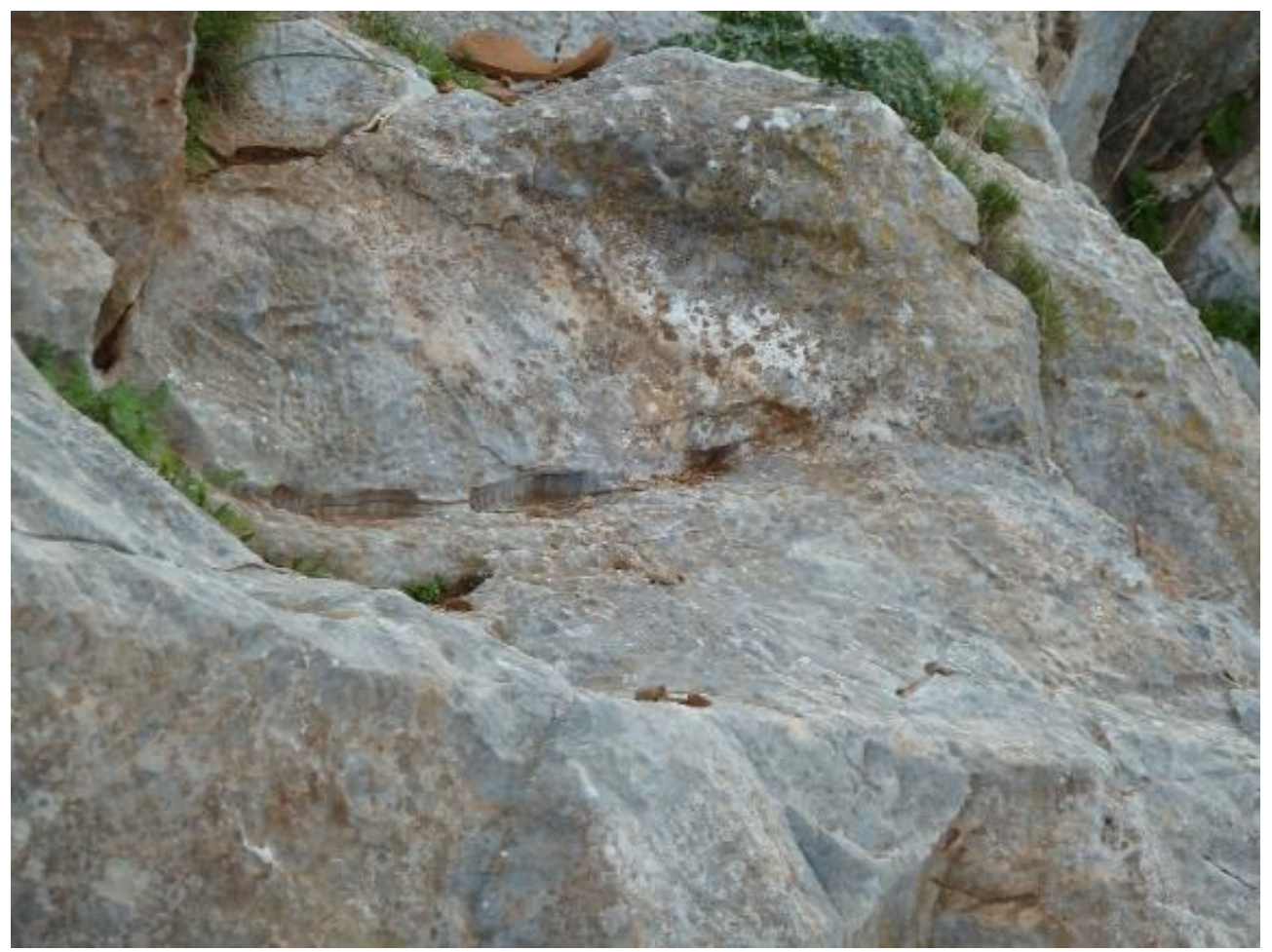

Figure 22: Quarried rock with wedge-holes at Kastraki, Agathonisi (photo by Eirene Poupaki).

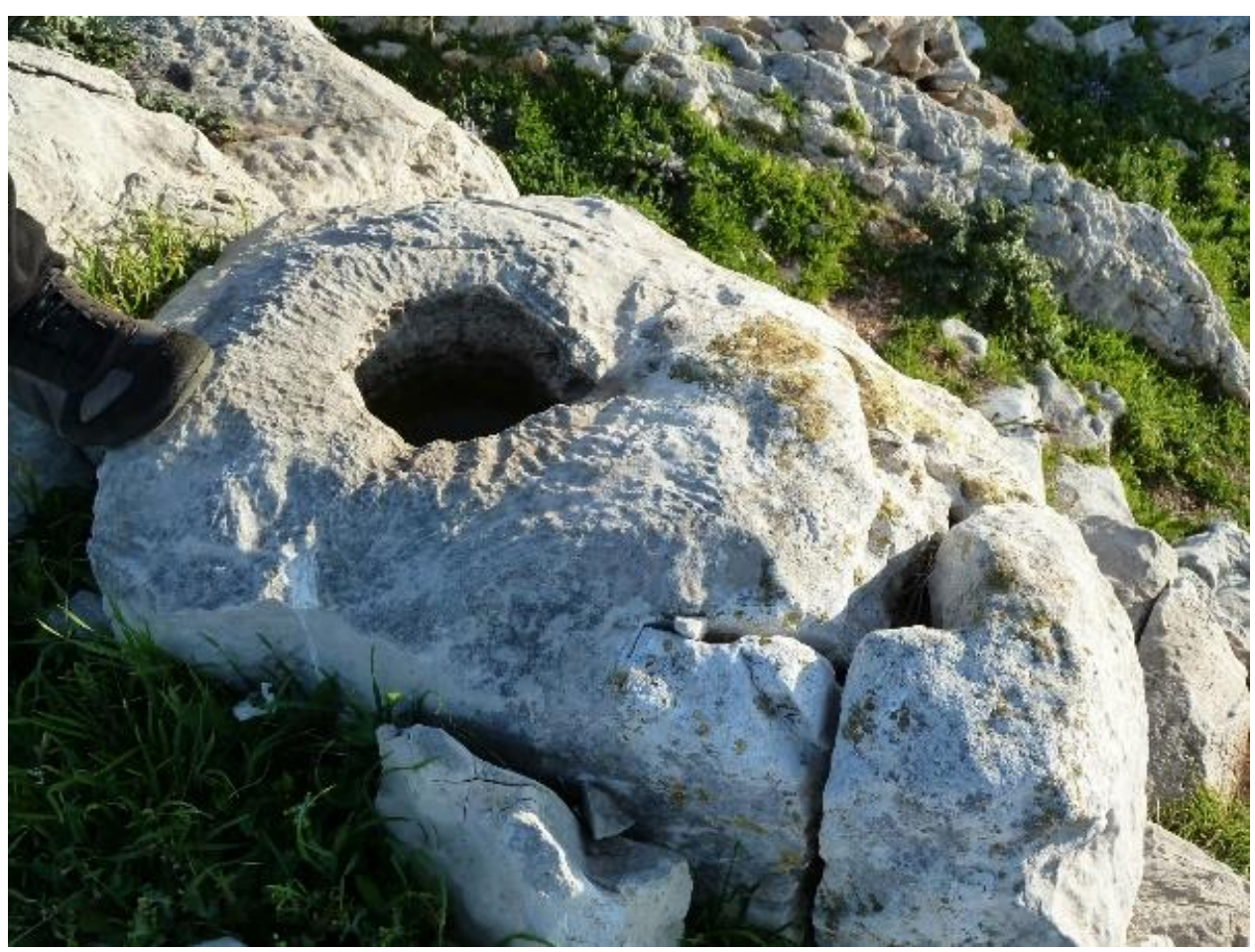

Figure 23: Pole-hole on the rock at Kastraki, Agathonisi (photo by Eirene Poupaki). 


\section{BIBLIOGRAPHIC REFERENCES}

Amouretti, M.-C. (1986). Le pain et l'huile dans la Grèce antique. De l'araire au Moulin, Annales Littéraires de l'Université de Besançon, vol. 67. Paris.

Anderson, T. J. (2003). Des artisans à la campagne : carrière de meules, forge et voie gallo-romaines à Châbles Fribourg. Editions Universitaires Fribourg, Fribourg.

Ardaillon, E. (1897). Les mines du Laurion dans l'Antiquité. Fontemoing, Paris.

Attanasio, D., Brilli, M. \& Ogle, N. (2006). The Isotopic Signature of Classical Marbles. L' Erma di Bretchneider, Roma.

Attula, R. (2006). Archaic Greek Plates from the Apollo Sanctuary at Emecik, Knidia. Results and questions concerning Dorian Pottery Production. In, Al. Villing \& Udo Schlotzhauer (Eds.), Naukratis: Greek diversity in Egypt. Studies on East Greek Pottery and Exchange in the Eastern Mediterranean, 85-92. The Trustees of the British Museum, London.

Boyer, F., Buchsenschutz, Ol., Hamon, C., Jaccottey, L., Lagadec, J.-P., Milleville, An., Thomas, Ém., \& Triboulot, B. (2006). Production et diffusion des meules du Néolithique à l'Antiquité : quelques exemples français. In Al. Belmont \& Fr. Mangartz (Eds.), Les Meulières. Recherche, protection et valorisation d'un patrimoine industriel européen (Antiquité - xxie siècle), Actes du colloque de Grenoble, 22-26 septembre 2005, 9-10. Römisch - Germanisches Zentralmuseum, Mayence.

Brecoulaki, H., Kavvadias, G. \& Verri, G. (2014). Colour and Luxury. Three Classical Painted Marble Pyxides from the Collection of the National Archaeological Museum of Athens. In, J. S. Østergaard \& A.M. Nielsen (Eds.), Transformations: Classical Sculpture in Colour (pp. 152-165). Carlsberg Glyptotek, Copenhague.

Brecoulaki, H. \& Kavvadias, G. (2019). Les pyxides de marbre peintes : un autre aperçu sur la peinture classique. In F. Gaultier, P. Rouillard \& Ag. Rouveret (Eds.), Céramique et peinture grecques dans la méditerranée antique. Du terrain au musée. Hommage à François Villard (pp. 213-234). De Boccard, Paris.

Chavane, M.-J. (1975). Les petits objets, Salamine de Chypre, VI. De Boccard, Paris.

Colivicchi, F. (1995). Vasellame marmoreo. In M. Mazzei (Ed.), ARPI. L'ipogeo della Medusa e la necropoli (pp. 271-284). Edipuglia, Bari.

Davidson, G.R. (1952). The minor objects, CORINTH XII. The American School of Classical Studies at Athens, Princeton, New Jersey. 
Déonna, W. (1938). Le mobilier Délien, Éxploration Archéologique de Délos XVIII. De Boccard, Paris.

De Sienna, Ant., Lazzarini, L. \& Cancelliere, S. (2012). Sui Materiali di una pisside marmorea greca di V secolo A.C. dipinta e configurata da Metaponto. Rivista di Archeologia XXXVI, 167-175.

Farget, V. (2006). Carrières, matériau et façonnages des productions en rhyolite des "Fossottes" de La Salle (Vosges) entre le Vie av. J.-C et le Ve siècle ap. J.-C. [Mémoire de maîtrise]. Université Paris-I Panthéon-Sorbonne.

Gaunt, J. (2013). The Classical marble pyxis and Dexilla's Dedication. In R.B. Koehl (Ed.), AMILLA. The quest for excellence. Studies presented to Guenter Kopcke in Celebration of his $75^{\text {th }}$ anniversary (pp. 381-398). INSTAP Academic Press, Philadelphia, Pennsylvania.

Goldman, H. (1950). Tarsus. Excavations at Gözlü Kule, Tarsus. Princeton University Press, Princeton, New Jersey.

Herda, Al., Brückner, H., Müllenhoff, M. \& Knipping M. (2019). From the Gulf of Latmos to Lake Bafa: On the History, Geoarchaeology, and Palynology of the Lower Maeander Valley at the Foot of the Latmos Mountains. Hesperia 88.1, 1-86.

Hellner, N. (2001). Die Säulen basen des zweiten Dipteros von Samos [Unpublished Doctoral Thesis]. München Universität.

Hiesel, G. (1967). Samische Steingeräte. Universität Hamburg, Hamburg.

Hoffelner, K. (1996). Die Sphinxsäule, (Votivträgen, Altäre, Steingeräte). In H. Walter \& E. Walter-Karydi (Eds.), Alt-Ägina II 4 (pp. 44-57). Philipp Von Zabern, Mainz am Rhein.

Holtmeyer-Wild, V. (2014). Preliminary report on a quern and millstone production site from the Iron Age and the Medieval Period at Mount Ruderbüsh, Western Eifel Region, Germany. In L. Selsing (Ed.), Seen through a millstone, AmS-Skrifter 24 (pp. 159-163). Museum of Archaeology, Stavanger University, Stavanger.

Jaccottey, L., Anderson, T. J. \& Jodry, F. (2007). La circulation du matériel de mouture de part et d'autre del' Arc jurassien durant l'Antiquité. In C. Bélet-Gonda, J.-P. Mazimann, An. Richard \& F. Schifferdecker (Eds.). Premières journées archéologiques frontalières de l'Arc jurassien. Actes. Delle (F) - Boncourt (CH), 21-22 octobre 2005. Mandeure, sa campagne et ses relations d'Avenches à Luxeuil et d'Augst à Besançon. Actualités archéologiques régionales (pp. 223-228). Presses 
Universitaires de Franche-Comté et Porrentruy, Office de la culture et Société jurassienne d'Émulation, Besançon.

Jasny, N. (1950). The daily bread of the ancient Greek and Romans. Osiris 9, 227-253.

Jodry, F. (2011a). Un Moulin par Conturbenium. In Strasbourg-Argentorate. Un camp légionnaire sur le Rhin (Ier au IV siècle après J-C) (pp. 107-108). Les Musées de la Ville de Strasbourg. Fouilles récentes en Alsace no. 8, Strasbourg.

Jodry, F. (2011b). Grès VS Basalte. L'exploitation du grès et l'importation du basalte en Alsace durant l'Antiquité (Ier-IIe siècle). In Ol. Buchsenschutz, L. Jaccottey, Fl. Jodry, J.-L. Blanchard (Eds.), Évolution typologique et technique des meules du Néolithique à l'an mille sur le territoire français. Chronique sur la table ronde de Saint-Julien-sur-Garonne (France) du 2 à l'octobre 2009. Aquitania supplementum 23, 401-408.

Jodry, F. (2011c). First Century Querns of the Roman Army, in the light of modern texts. In D. Williams-D. Peacock (Eds.), Bread for the people: the archaeology of mills and milling, Proceedings of a colloquium held in the British School at Rome $4^{\text {th }}$ $7^{\text {th }}$ November 2009, BAR International Series 2274 (pp. 85-91). Archeopress, Oxford.

Jucker, In. (1970). Aus der Antikensammlung des Bernischen Historischen Museums. Francke Verlag, Bern.

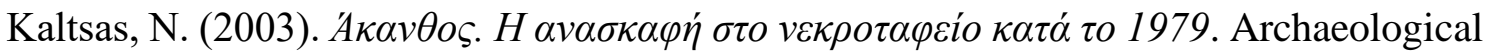
Resources Fund, Athens.

Katerinopoulos, Ath., Kokkorou-Alevra, G., Mavrogonatos, K. \& Poupaki, Eir. (2016). Volcanic Millstones from Ancient Halasarna, Kos Island. Mineralogy, Geochemistry and Comparison of Archaeological Samples to Rock Samples from Ancient Quarries on Kos and Nisyros, Dodecanese, Greece. HEROM 5.2, 161-197.

Katerinopoulos, Ath., Mavrogonatos, K. \& Poupaki, Eir. (2017). Avó $v v \sigma \eta$

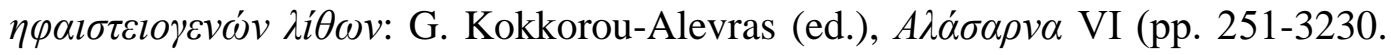

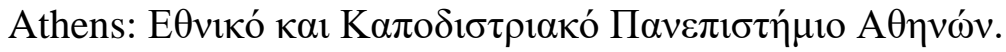

Kokkorou-Alevras, G., Eir. Poupaki, Al. Eustathopoulos \& Ach. Chatziconstantinou, (2014).

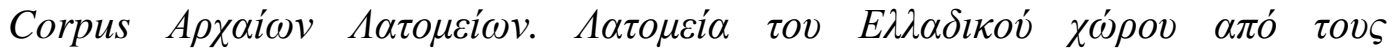

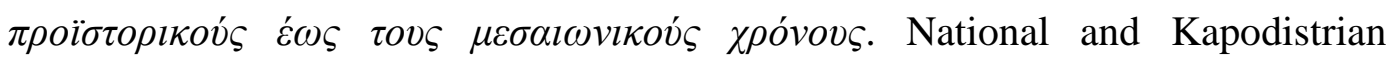
University of Athens, Athens. 
Lazzarini, L. \& St. Cancelliere (2000). Characterization of the white marble of two unpublished ancient Roman quarries of the islands of Fourni and Skyros (Greece). Periodico di Mineralogia 69.1, 49-62.

Maffre, J.-J. (1975). Collection Paul Canellopoulos : Vases Béotiens. Bulletin de la Correspondance Hellénique 99, 409-520.

Mangartz, F. (2006). Vorgeschichtliche bis mittelalterliche Mühlsteinproduktion in der Osteifel. In Al. Belmont \& Fr. Mangartz (Eds.), Les Meulières. Recherche, protection et valorisation d'un patrimoine industriel européen (Antiquité - xxie siècle), Actes du colloque de Grenoble, 22-26 septembre 2005 (pp. 25-34). Römisch - Germanisches Zentralmuseum, Mayence.

Mylonas, G. (1959). Agios Kosmas. An early bronze age settlement and cemetery in Attica. N. J. Princeton University Press, Princeton.

Neils, J. (2004). Kitchen or Cult? Women with Mortars and Pestles. In S. Keay \& S. Moser (Eds.), Greek Art in View. Essays in Honor of Brian Sparkes (pp. 54-62). Oxbow, Oxford.

Osborne, R. (2003). The Economy and Trade. In Cambridge Ancient History. Cambridge University Press: Cambridge ( $2^{\text {nd }}$ edition $)$.

Panitsa, M. \& D. Tzanoudakis (1998). Contribution to the Study of the Greek Flora: Flora and Vegetation of the E Aegean Islands Agathonisi and Pharmakonisi. Willdenowia 28. 1 (pp. 95-116).

Parton, H. (2013). Milling and Weaving Equipment, including hand-held stone tools, mortars, querns and stone vessels, loom weights, and spindle-whorls. In W. Aylward (Ed.), Excavations at Zeugma, Conducted by Oxford Archaeology, Vol. 3 (pp. 295-344). The Packard Humanities Institute, Los Altos, California.

Peshlow-Bindokat, A. (1981). Die Steinbrüche von Milet und Herakleia am Latmos. Jahrbuch des Deutchen Archäologishen Instituts 96, 157-235.

Peshlow-Bindokat, A. (1994). Steinbruch und Tempel. Die Cave di Cusa von Selinunt und die Marmorbrüche von Milet. Antike Welt 25, 122-139.

Peshlow-Bindokat, A. (1996). Der Latmos. Eine unbekannte Gebirgslandschaft an der türkischen Westküste, Sonderhefte der Antiken Welt. Philipp von Zabern, Mainz am Rhein.

Poblome, J. (2012). “Our Daily Bread” at Ancient Sagalassos. In M. Cavalieri (ed.), Industria Apium. L'archéologie : une démarche singulière, des pratiques multiples. 
Mare Nostrum, ano 2021, v. 12, n. 2

Hommages à Raymond Brulet (pp. 81-94). Presses universitaires de Louvain, Louvain-la-Neuve.

Pottier, Ed. (1900). Le sujet de genre dans les figurines archaïques de terre-cuite. Bulletin de la Correspondance Hellénique 24, 510-523.

Poupaki, Eir. (2000). Entries nos. 85-90. In L. Parlama \& N. Stampolides (Eds.), H Пó $\eta$

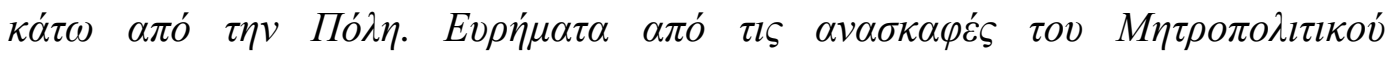

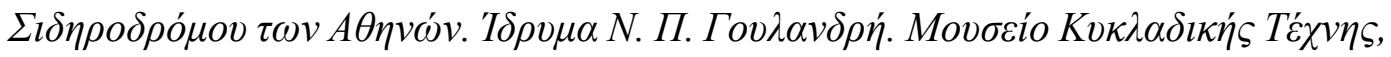

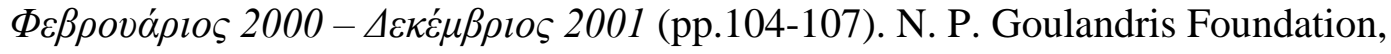
Museum of Cycladic Art, Athens.

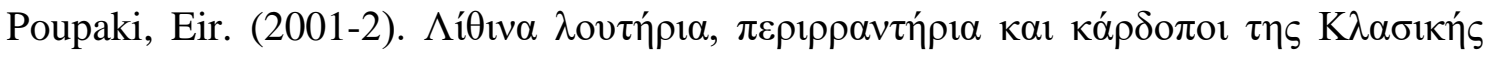

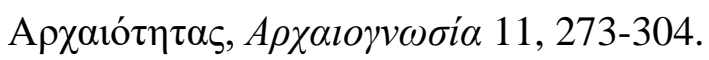

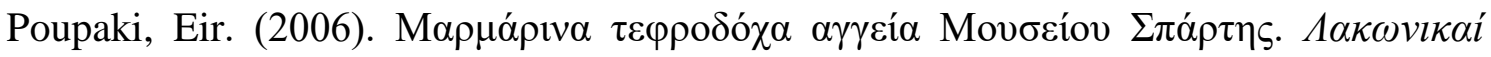

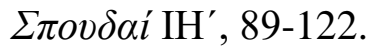

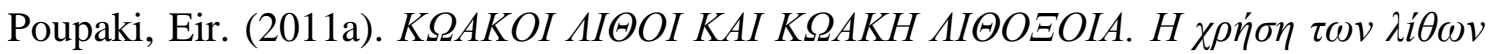

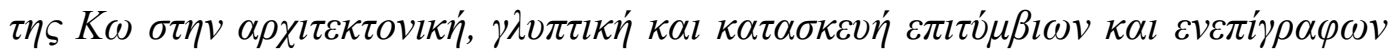

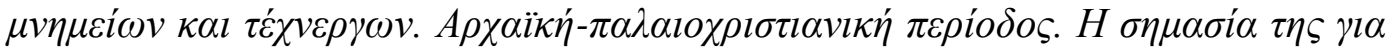

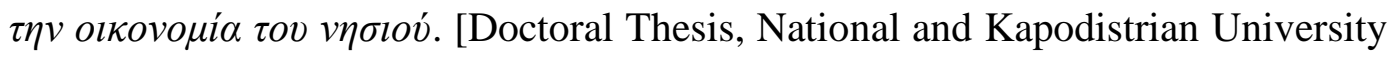
of Athens]. Repository of National Documentation Center: http://phdtheses.ekt.gr/eadd/handle/10442/27083

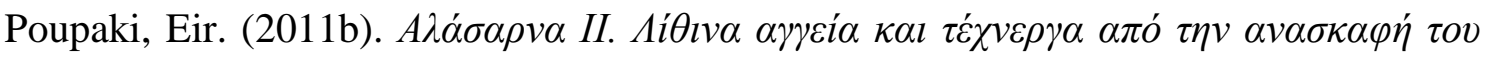

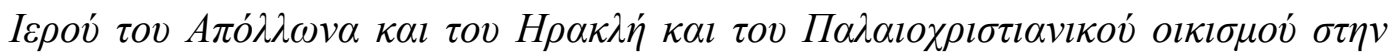

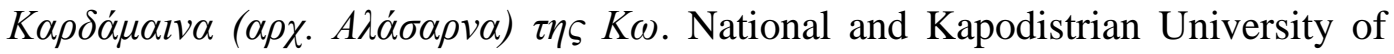
Athens, Athens.

Poupaki, Eir. (2014-15). Hand mills from the vicinity of the Athenian Acropolis. Finds from Athenian Metropolitan Railway Excavations, EYAIMENH 15-16, 11-53.

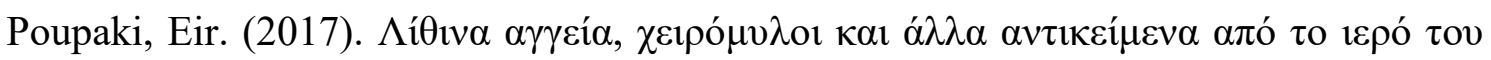

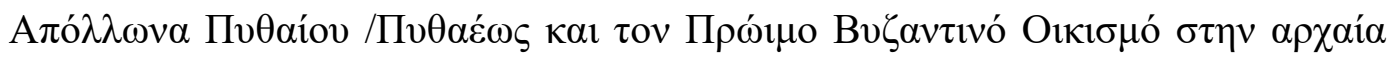

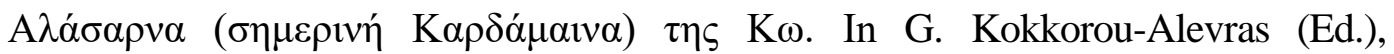

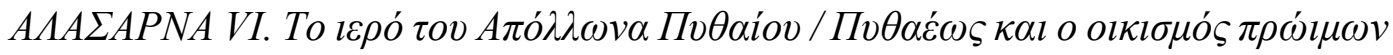

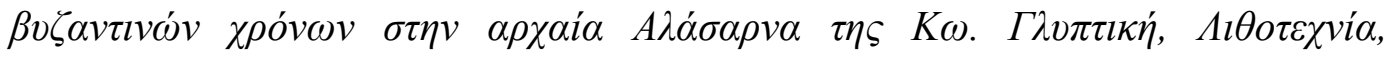

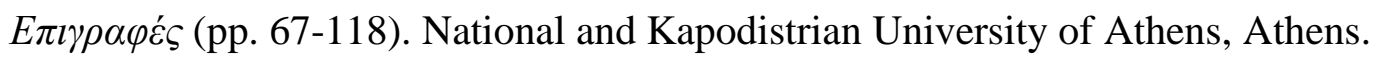

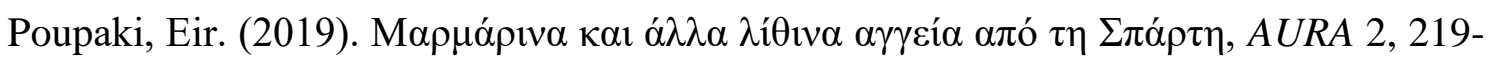
244. 


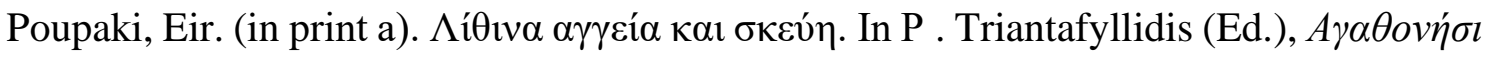

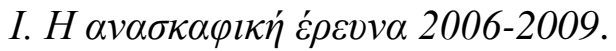

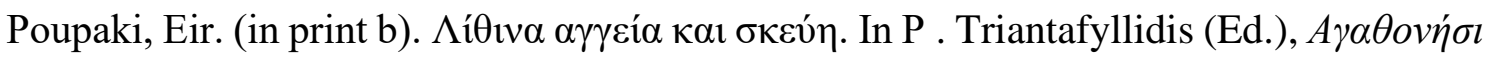
II. $H \alpha v \alpha \sigma \kappa \alpha \varphi \imath \kappa \eta ́ ~ \varepsilon ́ \rho \varepsilon v v \alpha ~ 2009-2014$.

Poupaki, Eir. (in print c). New Evidence about the Nisyrian Millstone Workshop. In E. Partida \& C. Graml (Eds.), Ergasteria. Premises and Processes of Creation in Antiquity. Archaeopress, Oxford.

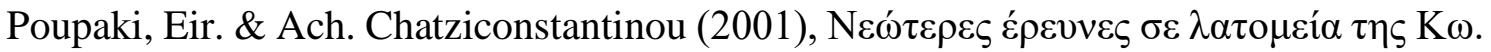

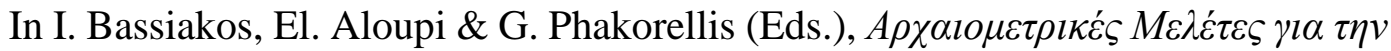

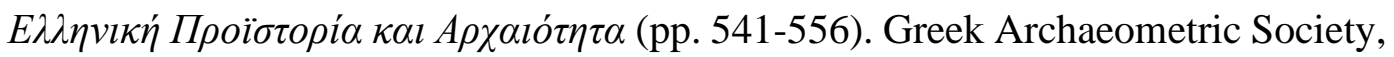
Athens.

Robinson, D. M. (1946). Architecture and Sculpture, Excavations at Olynthus II. Johns Hopkins University, Baltimore.

Runnels, C. (1988). Early bronze age stone mortars from the Southern Argolid, Hesperia $57.3,257-272$.

Sackett L. H. \& Cocking J. (1992). Other finds in Stone, Clay and Faience. In Sackett L. H. (Ed.), Knossos, from Greek City to Roman Colony. Excavations at the Unexplored Mansion II (pp. 391 - 414). Thames and Hudson, The British School at Athens, Oxford.

Salles J. F. \& M. J. Chavane (1993). Les Petits Objets. In J. F. Salles (Ed.), Les niveaux hellénistiques. Kition - Bamboula IV, (pp. 331-339). Éditions Recherche sur la Civilisation, Paris.

Sarantidis, K. (2015). An ancient roofing system from Kastraki on Milesian Agathonisi. In Er. Lafli \& S. Pataci (Eds.), Recent Studies on the Archaeology of Anatolia (pp. 113-118). Archaeopress, Oxford.

Sarantidis, K. (2020). Milesian Islands. The fortified installations in the insular environment of Miletus in the Aegean in context, Thiasos Monografiae 15. Edizioni Quasar, Roma.

Sparkes, B.A. (1962). The Greek Kitchen, JHS 82, 121-137.

Takaoğlu, T. (2008). Archaeological Evidence from grain mills in the Greek and Roman Troad. In Eng. Winter (Ed.), 'Vom Euphrat bis zum Bosporus Kleinasien in der Antike Festschrift für Elmar Schwertheim Zum 65. Geburtstag', AsiaMinorStudien 65. 2, 673-680. 
Mare Nostrum, ano 2021, v. 12, n. 2

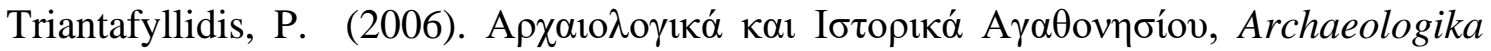
Analekta Ex Athinon 39, 175-192.

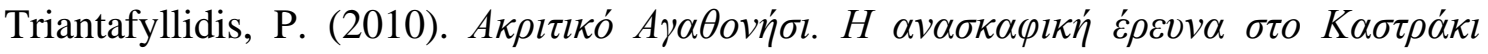
(2006-2010), Prefecture of Dodecanese, Athens.

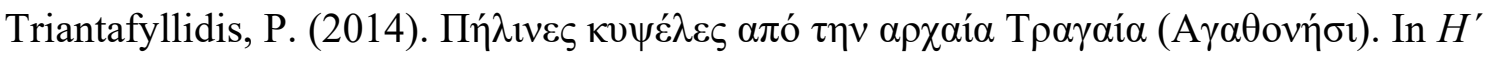

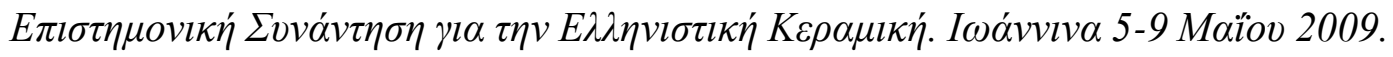

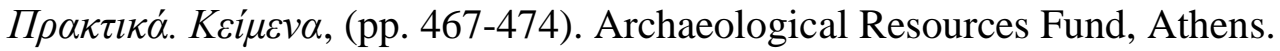

Triantafyllidis, P. (2015). Archaeological researches on Milesian Agathonisi in the Dodecanese, Greece. In Er. Lafli \& S. Pataci (Eds.), Recent Studies on the Archaeology of Anatolia (pp. 95-104). Archaeopress, Oxford.

Triantafyllidis, P. \& I. Karatasios (2015). Production technology of the ancient terracotta beehives on Milesian Agathonisi Island. In Er. Lafli \& S. Pataci (Eds.), Recent Studies on the Archaeology of Anatolia (pp. 105-111). Archaeopress, Oxford.

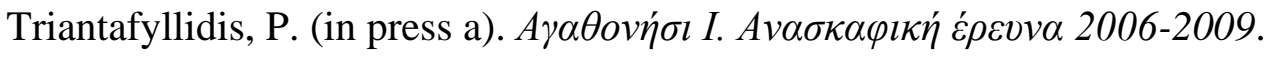

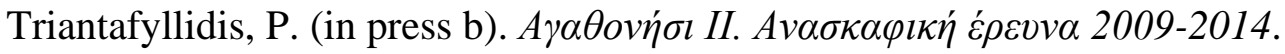

Tsakos, K. \& M. Viglaki-Sofianou (2012). Samos. The archaeological Museums, John S. Latsis Public Benefit Foundation, Athens.

Tsoukala, V. (2009). Cereal processing and the performance of gender in Archaic and Classical Greece: iconography and function of a group of terracotta statuettes and vases. In Çiğgdem Özkan Aygün (Ed.), SOMA 2007: Proceedings of the XI Symposium on Mediterranean Archaeology, Istanbul Technical University, 24 and 29 April 2007, BAR International Series 1900 (pp. 387-395). Archaeopress, Oxford.

Türkmen, B. (2009). Allianoi 'da bulunan ezme ve ögütme taş aletleri ile taş kaplar [Doctoral Thesis, Edirne Üniversitesi]. https://www.yumpu.com/tr/document/read/16733201/allanoda-bulunan-ezme-veogutme-tas-aletleri-ile-tas-kaplar

Tziligkaki El. K. \& M. G. Stamatakis (2018). Underground quarries in the area of Agiades, Samos island, Greece: notes on historical topography and chronology, Bulletin of Geological Society of Greece 53, 161-192.

Wagner, C. (1997). Dedication practices on the Athenian Acropolis $8^{\text {th }}$ to $4^{\text {th }}$ centuries B.C. [Doctoral Thesis, Merton College, University of Oxford, Trinity Term]. https://www.academia.edu/7062914/Dedication_Practices_on_the_Athenian_Acr opolis_8th_to_4th_Centuries_BC_Thesis_Oxford_1997 
Wefers, St. (2011a). Latènezeitliche Handdrehmühlen im nordmainischen Hessen. In Al. Belmont \& Fr. Mangartz (Eds.), Mühlsteinbrüche. Erforschung, Schutz und Inwertsetzung eines Kulturerbeseuropäischer Industrie (Antike-21. Jahrhundert), Internationales Kolloquium Grenoble - 22. bis 25. September 2005 - Maison des Sciences de l'Homme-Alpes (pp. 15-24). Römisch-Germanischen Zentralmuseums, Mainz.

Wefers, St. (2011b). Late Iron Age rotary querns between the Mayen and Lovosice Quarry Districts, International Molinology 82.2, 1-5.

Wiegand, T. \& H. Schrader (1904). Priene. Georg Reimer, Berlin.

Zaphiropoulou, F. (1973). Vases et autres objets de marbre de Rhénée, In 'Études Déliennes : Publiées à l'occasion du centième anniversaire du début des fouilles de l’École Française d'Athènes à Délos', Bulletin de la Correspondance Hellénique suppl. 1, 601-636 
Mare Nostrum, ano 2021, v. 12, n. 2

\section{Artefatos De Pedra De Agathonisi, Dodecaneso, Grécia: EVIDÊNCIAS DE INSULARIDADE}

Eirene Poupaki

RESUMO

A escavação sistemática em Kastraki da ilha de Agathonisi revelou os restos de um porto fortificado, que desenvolveu contatos comerciais e políticos com Mileto, a metrópole jônica, e outras cidades da Ásia Menor, assim como com suas ilhas vizinhas ou remotas. Estas conclusões foram fornecidas pelos achados bem estudados da escavação e podem ser confirmadas pelos artefatos de pedra não publicados, como vasos, querns e ferramentas, que serão apresentados aqui. Eles foram esculpidos em rochas locais ou importadas. A investigação de sua origem elucida a questão da insularidade, ou seja, de isolamento e conectividade.

PALAVRAS-CHAVE

Agathonisi, Dodecaneso, Pedra, Vasos, Kernos. 